SALAZAR, Andrés. "El delito de mantención de la venta de alimentos defectuosos al público: Una revisión del artículo 315 del Código Penal a partir de la teoría de las presunciones y de la dogmática de los delitos de omisión propia”.

Polit. crim. Vol. 10, N 19 (Julio 2015), Art. 11, pp. 318-361.

[http://www.politicacriminal.cl/Vol_10/n_19/Vol10N19A11.pdf]

\title{
El delito de mantención de la venta de alimentos defectuosos al público: Una revisión del artículo 315 del Código Penal a partir de la teoría de las presunciones y de la dogmática de los delitos de omisión propia*"
}

\section{The crime of maintaining the sale to the public of defective food products: A review of article 315 of the Penal Code from the theory of presumptions and dogmatic of felonies of own omission.}

\author{
Andrés Salazar Cádiz. \\ Máster en Derecho Penal, Universidades de Barcelona y Pompeu Fabra. \\ andresalazarc@gmail.com
}

\begin{abstract}
"El que una sentencia sea o no la formulación de una norma jamás puede decidirse sobre fundamentos mórficos, es decir, sobre la base de un signo (...) sería el uso de la expresión y no su aspecto lo que determinaría si es la formulación de una norma u otra cosa”.

G.H. von Wright ${ }^{1}$.

"...Un significado de una palabra es una forma de utilizarla”.

Ludwig Wittgenstein ${ }^{2}$.
\end{abstract}

\section{Resumen}

El presente estudio afirma que en nuestro país constituye delito el hecho de mantener productos alimenticios defectuosos a la venta, conducta que se encontraría tipificada en el inciso $3^{\circ}$ del artículo 315 de nuestro Código Penal. A juicio del autor, la constatación de la existencia de dicho ilícito ha pasado desapercibida para la mayor parte de nuestra doctrina porque el legislador ha utilizado para su tipificación palabras que poseen, en una primera acepción, un uso consolidado por parte de la profesión jurídica. En particular, el autor se refiere al empleo de la voz "presunción", expresión a la cual, corrientemente, los juristas le atribuyen la virtud de hacer referencia a una regla probatoria especial. Sin embargo, dicho significado no es el único que puede atribuirse a aquella palabra: en ciertos contextos

\footnotetext{
* Quisiera agradecer tanto los comentarios realizados por la profesora Dra. Mirentxu Corcoy Bidasolo como las opiniones brindadas por Daniela Palma Rodríguez durante la redacción del presente artículo. Obviamente, los errores que puedan subsistir en el presente artículo se deben exclusivamente a la obstinación de su autor.

${ }^{1}$ VON WRITH, George, Norma y acción. Una investigación Lógica, Madrid: Editorial Tecnos, 1970, p. 117.

${ }^{2}$ WITTGENSTEIN, Ludwig, Sobre la certeza, Barcelona: Editorial Gedisa, 2006, p. 10.
} 
SALAZAR, Andrés. "El delito de mantención de la venta de alimentos defectuosos al público: Una revisión del artículo 315 del Código Penal a partir de la teoría de las presunciones y de la dogmática de los delitos de omisión propia".

jurídicos, el uso de la voz "presunción" implica la decisión del legislador de establecer relaciones de equivalencia entre dos conceptos. Esto es lo que el autor denomina el "efecto constitutivo" de las presunciones en el Derecho. Siendo ésta una postura susceptible de ser controvertida, el presente artículo intenta justificar dicha premisa a través de una serie de argumentos de orden pragmático. Una vez demostrado este punto, será posible apreciar con mayor claridad el real contenido proposicional, sentido y alcance, del inciso $3^{\circ}$ del artículo 315 del referido estatuto legal.

Palabras clave: Norma, proposición normativa, reglas constitutivas, presunción, omisión, delitos de posesión, responsabilidad penal por el producto, producción, distribución y venta de productos defectuosos, mantener a la venta productos defectuosos, lugar público.

\begin{abstract}
This article argues that in our country it is an offence to keep defective food products in stock for sale, conduct which would be criminalized under article 315, paragraph 3 of our Penal Code. In the author's view, the existence of such an offence has passed unnoticed for most of our doctrine, because in the description of the prohibited conduct the law uses words that have, in a first or ordinary meaning, a consolidated use in law practice. In particular, the author analyzes the use of the word "presumption", which has been commonly understood by lawyers as referring to a particular rule of proof. However, that meaning is not the only one that can be attributed to that word: in certain legal contexts, the use of the word "presumption" implies the decision of the law-maker to establish a relation of equivalence between two concepts. This is what the author calls the "constitutive effect" of presumptions in law. Being this an arguable position, this article will try to justify such premise through a series of pragmatic arguments. Once this point has been proven, it will be possible to clearly appreciate the real content of article 315 paragraph 3 of the Penal Code.
\end{abstract}

Key words: Norm, normative proposition, constitutive rules, presumption, omission, possession crimes, criminal liability for defective products, production, distribution and sale of defective products, keep defective products in stock for sale, public place.

\title{
Introducción.
}

Contemporáneamente, se ha consolidado a tal punto la tendencia a distinguir entre norma, enunciados normativos y proposiciones normativas que hoy en día constituye un lugar común el recurrir a dicha taxonomía entre quienes se dedican a la Teoría del Derecho. De acuerdo con dicha distinción una norma (jurídica) sería, en buenas cuentas, una entidad que define el estatus deóntico de una determinada acción (frente al Derecho), esto es, determina si un comportamiento se encuentra permitido, prohibido o requerido, para un determinado agente, bajo determinadas circunstancias; por su parte, con la denominación "enunciado normativo" o "formulación de una norma" nos referimos a la concreta plasmación lingüística de una determinada norma, esto es, "el signo o símbolo (las palabras) usadas 
Polít. crim. Vol. 10, № 19 (Julio 2015), Art. 11, pp. 318-361.

[http://www.politicacriminal.cl/Vol_10/n_19/Vol10N19A11.pdf]

para enunciar (formular) una norma"3. Así, por ejemplo, en nuestro país la norma "no matarás" se encuentra expresada bajo el enunciado normativo "el que mate a otro será castigado con la pena de...". Finalmente, una proposición normativa constituye una afirmación que versa acerca de la existencia o inexistencia (vigencia) de una determinada norma, en un concreto sistema normativo. Así por ejemplo, puede afirmarse (con valor de verdad) que en Chile existe una norma (jurídica) que prohíbe dar muerte a otra persona.

La distinción entre proposición normativa y norma es relevante debido a que, a diferencia de estas últimas, respecto de las proposiciones normativas sí se puede predicar su verdad o falsedad; por su parte, las normas simplemente pueden ser justas, validas o eficaces, pero no son (ni pueden ser) ni verdaderas ni falsas ${ }^{4}{ }^{5}$. Por su parte, la distinción entre norma y enunciado normativo resulta relevante ya que la determinación de una norma y su concreto contenido depende semánticamente de su plasmación lingüística. Como señala von Wright, las normas son conceptualmente superiores a las valoraciones, precisamente, porque dependen del lenguaje.

Lo anterior es consistente con la distinción analítica planteada desde antiguo por la dogmática penal entre normas de comportamiento y normas de sanción (o normas primarias y secundarias). En este sentido, tal y como ha planteado el profesor Mañalich las normas (de comportamiento) si bien pueden no encontrarse explícitamente incorporadas en un determinado tipo penal (norma de sanción, o enunciado normativo) pueden ser inferidas a partir de su literalidad ${ }^{6}$.

El presente trabajo asume como correctas todas estas consideraciones y, a través de ellas, pretende plantear la existencia de una norma jurídico-penal que, a nuestro juicio, ha pasado desapercibida entre nosotros (tanto para la jurisprudencia como para la dogmática penal). Durante las próximas líneas sostendremos que en nuestro Derecho existe un delito de

\footnotetext{
${ }^{3}$ VON WRIGHT, Norma y Acción, cit. nota $\mathrm{n}^{\circ}$ 1, p. 109; DEL MISMO, Normas, verdad y lógica. México: Editorial Fontamara, 2010, pp. 24-26.

${ }^{4}$ En este sentido, BULYGUIN, Eugenio, "La importancia de la distinción entre normas y proposiciones normativas", en: BULYGUIN, Eugenio; ATIENZA, Manuel; BAYÓN, Juan Carlos, Problemas lógicos en la teoría y práctica del Derecho. Madrid: Fundación Coloquio Jurídico Europeo, 2009, p. 10.

${ }^{5}$ Un ejemplo pude clarificar la distinción: una "idéntica proposición verbal puede denotar una norma o una proposición normativa (...) "[a]quí no se debe fumar" es un enunciado que puede ser interpretado de dos maneras: a) como la formulación de una norma en tal sentido, cando el sujeto tiene la intención de hacerlo y utiliza el lenguaje en un sentido prescriptivo", por ejemplo, prohibiendo que en el interior del Bar que él administra los clientes realicen la acción de fumar (que por lo tanto, está prohibida) o "b) como la descripción de una norma existente, cuando la expresión se usa sólo para informar de dicha prohibición", como cuando alguien le informa a su acompañante, luego de ingresar al mismo Bar, "aquí no se debe fumar" (en este Bar se encuentra prohibido fumar). Sólo esta segunda afirmación es susceptible de ser verificada (por ejemplo, preguntándole al dueño si es verdadero o falso que rija tal prohibición en aquel lugar), mientras que en su primera denotación no tiene sentido la pregunta por la verdad o falsedad del enunciado. Al respecto: OSSANDÓN, María Magdalena, La Formulación de Tipos Penales. Santiago: Editorial Jurídica de Chile, 2009 , p. 77.

${ }^{6}$ MAÑALICH, Juan Pablo, Norma, Causalidad y Acción, Madrid: Editorial Marcial Pons, 2014, p. 16. Al respecto señala este autor que "[1]a realización (imputable) del tipo básico de un determinado género delictivo se corresponde con el quebrantamiento (imputable) de la norma "primaria" de comportamiento susceptible de ser pragmáticamente inferida de la correspondiente norma "secundaria" de sanción, esto es, de aquella cuyo supuesto de hecho (atómico) se identifica con ese mismo tipo de "delito genérico".
} 
SALAZAR, Andrés. "El delito de mantención de la venta de alimentos defectuosos al público: Una revisión del artículo 315 del Código Penal a partir de la teoría de las presunciones y de la dogmática de los delitos de omisión propia”.

omisión propia que se configura por la mantención a la venta de productos alimenticios que se hayan transformado en nocivos para la salud de las personas y que tal ilícito se encuentra previsto en el inciso $3^{\circ}$ del artículo 315 del Código Penal.

A nuestro juicio, dicha inadvertencia se ha cimentado en un deficiente uso del lenguaje, particularmente, en lo que dice relación con la interpretación de una expresión: "se presumirá”. Como se verá más adelante, creemos que el uso consolidado de la expresión "presunción" como referido únicamente a una regla de carácter probatorio ha oscurecido y ocultado otros usos lingüísticos que son posibles de atribuir a la mencionada locución en el contexto jurídico. En particular, estimamos que la costumbre que los juristas han desarrollado de asociar inmediatamente (casi intuitivamente) el contenido de una regla que hace uso de la expresión "presunción" o "se presumirá" a una norma de carácter adjetivo, les ha impedido ver con claridad que dicha palabra puede tener otras acepciones (usos) relevantes como lo es el hecho de constituir o declarar (cuando es utilizada en un sentido realizativo).

Para ello, y en apoyo de nuestra tesis, pretendemos demostrar que en nuestro Derecho existen varios ejemplos a través de los cuales la voz presunción ha adquirido un significado distinto al que le es usualmente asignado entre nosotros y que, siendo esto así, deberían desprenderse importantes consecuencias para la norma en estudio (y posiblemente para otras normas de sanción diseminadas a través de nuestro ordenamiento jurídico-penal).

Finalmente, una vez establecido el verdadero carácter deóntico de la regla prevista en el inciso $3^{\circ}$ del artículo 315 del Código Penal (en adelante CP), esbozaremos, someramente, el que creemos debe ser el alcance del mandato o requerimiento contenido en ella.

En buenas cuentas, como se verá, el presente trabajo tiene por finalidad la afirmación de una proposición normativa y su verificación, procedimiento que implicará, en caso de resultar exitoso, el develamiento de una norma jurídico-penal que, a pesar de su importancia, habría pasado desapercibida por ya mucho tiempo.

Pero, antes de iniciar dicha argumentación deberemos emprender un breve estudio del artículo 315 del CP, por ser éste el contexto donde se inserta la regla que pretendemos develar. En este orden de ideas, estimamos que resultará instructivo repasar lo que ha dicho nuestra jurisprudencia a propósito de la posibilidad de reprimir conductas omisivas a través de los tipos penales (tradicionalmente considerados como) incluidos en dicha disposición, ya que aquella postura institucional, a nuestro juicio, revelará con mayor fuerza la función que debería ser asignada al mencionado inciso $3^{\circ}$.

\section{Acerca de la interpretación de los incisos primero y segundo del artículo $315 \mathrm{CP}$ y de la posibilidad de castigar conductas omisivas a través de dichas normas.}

El artículo 315 del CP se encuentra inserto en el párrafo 14 del Título VI del Libro II del Código Penal, párrafo que ostenta la denominación de "Crímenes y delitos contra la salud pública". 
Polít. crim. Vol. 10, № 19 (Julio 2015), Art. 11, pp. 318-361.

[http://www.politicacriminal.cl/Vol_10/n_19/Vol10N19A11.pdf]

La actual redacción de las reglas contenidas en dicho acápite (esto es, de los artículos 313a hasta el artículo 318) constituye el resultado de la reforma introducida al Código Penal en el año 1969 por la Ley $\mathrm{N}^{\circ} 17.155$ que tuvo por objeto declarado el perfeccionamiento de "las disposiciones que sancionan los delitos contra la salud pública" cuya configuración resultaba ya para el legislador de la época "absolutamente inadecuad[a] (...) frente a las múltiples formas de atentado que las técnicas y condiciones de vida moderna hacen posible",

Como se podrá apreciar más adelante, para nuestros efectos resulta de interés hacer notar que varias de las reglas contenidas en el mencionado párrafo constituyen lo que en la actualidad podríamos denominar como "nuestras" normas de "responsabilidad penal por el producto" 8 . En otras palabras, con el recurso a la mencionada categorización se quiere decir que dichas disposiciones forman parte de aquel sector del ordenamiento jurídico que

\footnotetext{
${ }^{7}$ Mensaje Presidencial, página 1. Incorporada a la Sesión $18^{\text {a }}$ de miércoles 23 de noviembre de 1966 de la Cámara de Diputados, p. 1683.

${ }^{8}$ La responsabilidad penal por el producto, hasta donde se alcanza a ver, salvo por notables excepciones, se trata de un tema prácticamente abandonado por nuestra dogmática, situación que no se condice con la importancia teórica y práctica de esta área del Derecho Penal. Y es que, tal y como hemos visto en la jurisprudencia y doctrina comparadas, el acaecimiento de un caso de aquellos que son habitualmente estudiados bajo este rotulo, implica para los operadores jurídicos que se enfrentan a aquél el abordaje forzoso de algunos de los temas más complejos y álgidos del Derecho Penal contemporáneo: la determinación de responsabilidades individuales en el contexto de organizaciones empresariales, de los nexos de causalidad existentes entre el riesgo o la lesión de los bienes jurídicos que son objeto de protección de las respectivas normas y el evento o producto defectuoso arrojado al mercado por el respectivo fabricante, entre otros. Si acaso fue la ausencia de grandes casos jurisprudenciales lo que llevó a esta actitud de indiferencia ante las normas penales que configuran nuestra "responsabilidad penal por el producto", dicho estado de cosas ya no posee justificación. Recientemente, el denominado caso ADN no sólo demostró que en nuestro país, al igual que en el resto del mundo, la producción defectuosa de alimentos puede poner en riesgo la vida o la integridad física de un gran grupo de individuos sino que, además, permitió observar in situ los problemas que se suscitan en sede de adjudicación a la hora de establecer, desde la perspectiva jurídico-penal, la concurrencia de las condiciones necesarias y suficientes que permiten la subsunción de un determinado suceso en las correspondientes reglas punitivas de la parte especial de nuestro Código Penal. Dada la extensión y el objeto que posee presente trabajo, no podremos hacernos cargo aquí del referido déficit dogmático y analizar todas y cada una de las referidas normas y las aristas interpretativas que puedan derivarse de un ejercicio de tal magnitud. Nuestro propósito es mucho más modesto. Finalmente, en nuestro país, podemos destacar las siguientes contribuciones al estudio del tema: ETCHEBERRY, Alfredo, Derecho Penal, Parte Especial, T.

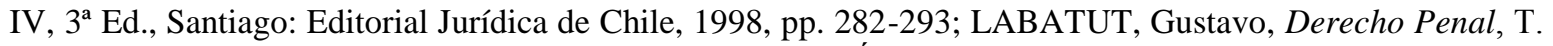
II., Santiago: Editorial Jurídica. 2000, pp. 287 y ss.; HERNÁNDEZ, Héctor, "El problema de la "causalidad general" en el derecho penal chileno (con ocasión del art. 232 del Anteproyecto de Nuevo Código Penal)", Polít. crim. n o 1 (2006), pp. 1-33; VAN WEEZEL, Alex, "Autoría y responsabilidad por el producto: ¿participación en decisiones de órganos colegiados como intervención delictiva?”, en: DEL MISMO, Pena y Sentido. Estudios de Derecho Penal, Lima: Editorial Ara, 2008, pp. 371-396; ZARATE, Manuel, "Delitos contra la salud pública. Algunos comentarios a partir de una sentencia condenatoria por el delito previsto en el artículo 314 del Código Penal", Revista Jurídica del Ministerio Público, No 37 (Diciembre 2008), pp. 240249; CONTRERAS, Lautaro, Criterios para la determinación de los deberes del productor, Santiago: Colegio de Abogados de Chile, 2012. Especialmente, debe destacarse que este último autor ha realizado el trabajo más importante entre nosotros, a través de su tesis doctoral, la cual fue publicada en Alemania bajo el título Normative Kriterien zur Bestimmung der Sorgfaltspflichten des Produzenten, Berlin: Editorial Duncker\&Humblot, 2012.
} 
SALAZAR, Andrés. "El delito de mantención de la venta de alimentos defectuosos al público: Una revisión del artículo 315 del Código Penal a partir de la teoría de las presunciones y de la dogmática de los delitos de omisión propia”.

pretende "delimitar en qué casos y en qué forma puede dar lugar a responsabilidad penal el ofrecimiento en el comercio de un objeto de consumo".

Dentro de estas disposiciones, tal y como se adelantó, la del artículo $315 \mathrm{CP}$ es la que tiene por objeto regular la responsabilidad penal que puede surgir a partir de la producción defectuosa de alimentos ${ }^{10}$.

Siendo entonces ésta la norma pertinente para nuestros fines, es menester revisarla con mayor detenimiento.

El texto íntegro del artículo 315 del Código Penal señala lo siguiente:

"Art. 315. El que envenenare o infectare comestibles, aguas u otras bebidas destinados al consumo público, en términos de poder provocar la muerte o grave daño para la salud, y el que a sabiendas los vendiere o distribuyere, serán penados con presidio mayor en su grado mínimo y multa de veintiuna a cincuenta unidades tributarias mensuales.

El que efectuare otras adulteraciones en dichas sustancias destinadas al consumo público, de modo que sean peligrosas para la salud por su nocividad o por el menoscabo apreciable de sus propiedades alimenticias, y el que a sabiendas las vendiere o distribuyere, serán penados con presidio menor en su grado máximo y multa de seis a cincuenta unidades tributarias mensuales.

Para los efectos de este artículo, se presumirá que la situación de vender o distribuir establecida en los incisos precedentes se configura por el hecho de tener a la venta en un lugar público los artículos alimenticios a que éstos se refieren. La clandestinidad en la venta o distribución y la publicidad de alguno de estos productos constituirán circunstancias agravantes.

Se presume que son destinados al consumo público los comestibles, aguas u otras bebidas elaboradas para ser ingeridos por un grupo de personas indeterminadas.

Los delitos previstos en los incisos anteriores y los correspondientes cuasidelitos a que se refiere el inciso segundo del artículo 317, sólo podrán perseguirse criminalmente previa denuncia o querella del Ministerio Público o del Director General del Servicio Nacional de Salud o de su delegado, siempre que aquéllos no hayan causado la muerte o grave daño para la salud de alguna persona. En lo demás, los correspondientes procesos criminales quedarán sometidos a las normas de las causas que se siguen de oficio.

No será aplicable al Ministerio Público ni a los funcionarios del Servicio Nacional de Salud respecto de estos delitos, lo dispuesto en los Nos. 1 y 3 del artículo 84, respectivamente, del Código de Procedimiento Penal”.

Como primera constatación, es evidente que la norma se encuentra circunscrita a una particular clase de productos: los alimentos ${ }^{11}$. Las consecuencias punitivas asociadas a la

9 CORCOY BIDASOLO, Mirentxu, "Responsabilidad penal derivada del producto. En particular la regulación legal en el Código Penal Español: Delitos de Peligro”. En: MIR PUIG, Santiago; LUZÓN PEÑA, Diego-Manuel, (Coords.), Responsabilidad Penal de las Empresas y sus Órganos y Responsabilidad por el Producto, Barcelona: Bosch Editor, 1996, p. 247.

${ }^{10}$ En este sentido, ETCHEBERRY, Derecho Penal, cit. nota $\mathrm{n}^{\circ}$ 8, pp. 228-289. Coincide también, CONTRERAS, Criterios, cit. nota $\mathrm{n}^{\circ} 8$, pp. 6 y ss.

${ }^{11}$ En este sentido, ETCHEBERRY. Derecho Penal, cit. nota ${ }^{\circ}$ 8, pp. 282-289. 
Polít. crim. Vol. 10, № 19 (Julio 2015), Art. 11, pp. 318-361.

[http://www.politicacriminal.cl/Vol_10/n_19/Vol10N19A11.pdf]

elaboración defectuosa de otro tipo de productos de especial potencialidad nociva para la salud de los seres humanos, como medicamentos u otras sustancias químicas riesgosas, se encuentran establecidas en otras disposiciones (a saber, en los arts. 313 d y $314 \mathrm{CP}$, respectivamente).

Del mismo modo, es fácil apreciar que los incisos primero y segundo del art. $315 \mathrm{CP}$ tienen por objeto la sanción de dos diferentes modalidades de conducta. El inciso primero reprime el envenenamiento o infección de aguas, bebidas o alimentos mientras que el inciso segundo castiga a quién efectuare otro tipo de adulteraciones sobre dichos elementos. Sin embargo, debe tenerse presente que todas estas conductas (vale decir, tanto las de envenenamiento e infección como las de adulteración) deben provocar un efecto concreto en las sustancias bebestibles o comestibles sobre las cuales recaen. De esta forma, en el primer caso, el tipo exige que, como consecuencia de la infección o el envenenamiento, los alimentos afectados adquieran la potencialidad de provocar la muerte o generar graves daños para la salud, mientras que, en el segundo caso, la adulteración deberá tornar en peligrosas esas mismas sustancias sea porque ellas se transformen en nocivas o porque al disminuir apreciablemente sus propiedades nutricionales la bebida o el alimento afectado adquiera también el carácter de riesgoso para su salud de los consumidores ${ }^{12}$.

Además, debe tenerse en consideración que los tipos contenidos en los incisos primero y segundo también castigan las posteriores conductas de distribución y venta de los alimentos infectados, envenados, adulterados o deteriorados, en los términos recién expuestos.

En este punto, es necesario aclarar que no existen razones que permitan reducir por vía interpretativa el alcance de delitos contemplados en los incisos $1^{\circ}$ y $2^{\circ}$ del art. $315 \mathrm{CP}$ a la mera penalización de hipótesis de sabotaje ${ }^{13}$ o fraude alimentario ${ }^{14}$, respectivamente. No

\footnotetext{
${ }^{12}$ En adelante, llamaremos a este último tipo de sustancias alimenticias defectuosas como "disminuidas" o "deterioradas".

${ }^{13}$ Hablamos de "sabotaje alimentario" cuando la contaminación o defecto que aqueja al producto alimenticio proviene de un ataque cometido por agentes externos a la organización empresarial responsable de la elaboración de los elementos nutricionales afectados. Labatut, pareciera insinuar una interpretación del alcance del inciso primero desde la perspectiva del sabotaje alimentario al requerir que la infección o envenenamiento provengan de una conducta "insidiosa", sin embargo, esta inferencia no puede ser calificada como concluyente dada la brevedad del comentario realizado por el mencionado autor a propósito del presente delito. Así, LABATUT, Derecho Penal, cit. nota $\mathrm{n}^{\circ}$ 8, p. 117. De todas formas, a partir de la mera posibilidad de una interpretación que entienda al delito del art. 315 en ese sentido, creemos conveniente hacerse cargo de la misma.

${ }^{14}$ En doctrina se emplea el rótulo "fraude alimentario" para designar a aquella conducta engañosa que "condiciona (...) una representación equivocada sobre las cualidades del alimento, consecuencia de su presentación o publicidad engañosa". Así, DANNECKER, Gerhard, "Derecho Penal Alimentario Europeo". en: TIEDEMANN, Klaus (Dir.), Eurodelitos. El Derecho Penal Económico en la Unión Europea, Cuenca: Ediciones Universidad de Castilla de la Mancha, 2003, p. 80. De acuerdo a Tiedemann lo que caracteriza al fraude alimentario es que aquella hipótesis delictiva castiga al empresario que no informa acerca de la divergencia que se hubiere producido entre una "versión comercial prevalente" del producto (como por ejemplo, respecto de su concreto contenido a nivel de composición elemental) y aquella que se pone efectivamente en circulación. Al respecto, TIEDEMANN, Klaus, Manual de Derecho Penal Económico: Valencia: Editorial Tirant Lo Blanch, 2010, p. 459.
} 
SALAZAR, Andrés. "El delito de mantención de la venta de alimentos defectuosos al público: Una revisión del artículo 315 del Código Penal a partir de la teoría de las presunciones y de la dogmática de los delitos de omisión propia".

existen razones de texto ${ }^{15}$, sistemáticas ${ }^{16}$, históricas o teleológicas ${ }^{17}$ que permitan avalar una interpretación de las referidas disposiciones en tal sentido.

Finalmente, debe destacarse que los tipos penales que nos encontramos estudiando se encuentran estructurados como delitos de peligro abstracto ${ }^{18}$. Esto es así, porque de la

${ }^{15}$ En lo que respecta a una interpretación del art. 315 CP como delito de "sabotaje alimentario" debe tenerse presente que, los estudiados tipos penales configuran delitos comunes, de sujeto activo abierto, por lo que admiten ser cometidos por cualquier persona, sea éste un outsider, sea el propietario de la empresa o un empleado de la misma. Bajo la misma lógica, tampoco existen datos lingüísticos que permitan entender a estos tipos como delitos de medios determinados, exigiendo la concurrencia de un engaño como condición necesaria para imponer la pena asignada a estos delitos. Muy por el contrario, dada la amplitud de la redacción de dichas normas, lo que sí es posible afirmar es que tanto el inciso $1^{\circ}$ como el inciso $2^{\circ}$ del art. 315 $\mathrm{CP}$ permiten castigar hipótesis de fraude alimentario, de sabotaje alimentario y de otras tantas e innumerables formas concretas de poner en riesgo la salud de los consumidores por la vía del envenenamiento, infección, adulteración o disminución de las propiedades nutricionales de los alimentos destinados al consumo público

${ }^{16}$ Podría pensarse que constituye un argumento a favor de esta interpretación el hecho de que estos tipos son considerados como delitos base de ilícitos terroristas. Sin embargo, la adscripción del artículo 315 CP dentro del catalogo de posibles ilícitos terroristas no fue una cuestión definida por el legislador de la Ley $\mathrm{N}^{\circ} 17.155$, quien, de acuerdo a lo que consta en la historia del precepto sólo quería proteger la salud de los consumidores. Es más, tanto el Decreto Ley 2.691 de 1979 como la actual Ley $\mathrm{N}^{\circ}$ 18.134, de mayo de 1984 son muy posteriores a la publicación de la Ley $\mathrm{N}^{\mathrm{o}} 17.155$, por lo que mal podría atribuirse la intención de asociar sus normas a hipótesis terroristas a un legislador que no tenía en su horizonte normativo una legislación penal de tal carácter. Finalmente, si de verdad se requiriese la concurrencia de un boicot urdido desde el exterior de la empresa, no se entiende por qué el legislador de la ley 17.155 decidió castigar en el artículo $317 \mathrm{CP}$ la realización imprudente de las conductas descritas en el Art 315, ya que, los deberes de cuidados propios de la fabricación de alimentos, lógicamente, sólo recaen sobre los hombros de los fabricantes de dichos alimentos.

${ }^{17}$ En primer lugar, de acuerdo con las actas que registran la historia de la Ley $\mathrm{N}^{\circ} 17.155$, es claro que durante la discusión parlamentaria nunca se tuvo a la vista, como objetivo prioritario, el utilizar la presente disposición como mecanismo para la protección de la posición del empresario que se ve afectado por una acción de sabotaje o la intención de las legitimas expectativas del consumidor que se ven defraudadas por medio del engaño (activo -concluyente- u omisivo) en que incurren productores, distribuidores o vendedores del producto adulterado. Muy por el contrario, todo indica que lo relevante para los legisladores a la hora de construir la norma de que se trata fue simplemente la potencialidad lesiva que poseería el producto fabricado o liberado al mercado bajo las deficitarias condiciones descritas por aquella disposición. En este sentido el mensaje presidencial reflexiona acerca de los déficits de la antigua legislación en la materia, enfatizando el hecho de que el Código Penal vigente a la época "ignora por completo las consecuencias que pueden producirse para la salud de la población a través de la preparación o expendio de sustancia nocivas a gran escala (...); ignora la rapidez y extensión con que puede difundirse el consumo de tales sustancias por el volumen de su fabricación, la rapidez de su transporte y le ingente propaganda difundida a través de toda clase de medios de publicidad...", etc. En suma, de lo dicho se puede inferir que la referida modificación tuvo como objetivo principal la adaptación de nuestra legislación penal al nuevo escenario económico-fabril, marcado por la incorporación de tecnología en todos los ámbitos de la industria, circunstancia que en el caso específico de la industria farmacéutica y alimenticia va de la mano de una amplificación de los alcances de los tradicionales riesgos que dichas actividades han implicado desde siempre para la salud individual. Por el contrario, durante toda la discusión no se observa que se le otorgue importancia fundamental al hecho de si ese riesgo concreto para la salud se ha creado a través de un engaño al consumidor, por un sabotaje causado terceros ajenos a la empresa elaboradora, o por otro tipo de consideraciones que vayan más allá de aquella circunstancia.

${ }^{18}$ CONTRERAS, Criterios, cit. nota ${ }^{\circ} 8$, pp. 6- 7. También, ETCHEBERRY, Derecho Penal, cit. nota ${ }^{\circ} 8$, p. 282, al momento de pronunciarse sobre los delitos del párrafo 14 del título IV del Libro II del CP; En el mismo sentido LABATUT, Derecho Penal, cit. nota $\mathrm{n}^{\circ}$ 8, p. 113, quién agrega que, desde su particular visión, “...solo se contemplan conductas que atentan o ponen en peligro la salud individual y que tal 
Polít. crim. Vol. 10, № 19 (Julio 2015), Art. 11, pp. 318-361.

[http://www.politicacriminal.cl/Vol_10/n_19/Vol10N19A11.pdf]

lectura del texto de ambos incisos se desprende que para castigar a quien produce, distribuye o comercia el producto alimenticio defectuoso no es necesario que las acciones prohibidas por la norma traigan como consecuencia concreta la lesión de la salud de uno o más consumidores. Es más, ni siquiera será necesario acreditar en juicio que persona alguna ha llegado, efectivamente, a consumir o siquiera tener en su poder el alimento, agua o bebida deteriorada o infectada. Abonando esta interpretación, huelga señalar que la Historia de la Ley es suficientemente clara al respecto ${ }^{19}$. El hecho de que los tipos contenidos en el mencionado artículo deban ser entendidos como delitos de peligro abstracto, tal y como se verá más adelante, resultará en extremo importante para la argumentación que se desarrollará.

Con esto, creemos haber repasado los rasgos fundamentales de las reglas punitivas contenidas en los dos primeros incisos del Artículo 315 del Código Penal. Ahora bien, tras la lectura de estas normas, cabe preguntarnos si constituye delito en nuestro país el omitir medidas adecuadas para evitar que los riesgos creados por la producción defectuosa de alimentos tiendan a concretarse.

Si nos atenemos exclusivamente a lo sostenido por nuestra jurisprudencia deberíamos conformarnos con una respuesta negativa ${ }^{20}$. En efecto, de acuerdo a lo consignado expresamente en el considerando decimocuarto de la sentencia del Tribunal Oral en lo Penal de San Bernardo emitida a propósito del conocido "Caso ADN", al analizar el artículo 315 inc. $2^{\circ}$ del Código Penal (uno de los tipos penales invocados por la parte acusadora), deberíamos entender que:

denominación [salud pública] no significa que exista un orden público de salud". También, parece adherir a dicha postura ZARATE, "Delitos", cit. nota n 8, pp. 244-246.

${ }^{19}$ De hecho, la Historia de la Ley demuestra que el legislador fue extremadamente consciente de estar creando (y querer crear) un delito de peligro abstracto. En este sentido, muy clarificadora se demuestra la discusión que tuvo lugar en la Cámara de Diputados en la 25ª Sesión del día martes 8 de Abril de 1969, a propósito de la redacción definitiva que debía adoptar esta norma. En pugna se encontraban dos redacciones, la propuesta por la cámara baja y el texto ideado por el Senado, que es el que se plasmó en definitiva en la disposición en estudio. Luego de un debate al respecto, las consideraciones expuestas por el H. Diputado Sr. Tejada fueron las que primaron para mantener el texto proveniente de la cámara alta, quién expresó que “...el artículo de la Cámara castiga sólo en el caso de que se expendan o distribuyan sustancias alimenticias inaptas, descompuestas, infectadas, envenenadas, etcétera; en cambio, el artículo del Senado aplica la sanción aunque no haya expendio, aunque no se distribuya, por el sólo hecho de envenenar o infectar los comestibles aguas u otras bebidas destinadas al consumo público, aunque no se usen, repito, siempre se castiga (...) además, castiga por el sólo hecho de envenenar las aguas o infectar los comestibles, aun cuando no se hayan expendido".

${ }^{20}$ Existen otros precedentes jurisprudenciales que han recaído sobre delitos contra la salud pública a propósito de la producción defectuosa de alimentos, sin embargo, en ellos no se planteó la posibilidad de castigar a sus autores por conductas omisivas sino sólo por su participación activa en la creación del riesgo proscrito. En este sentido por ejemplo la Sentencia de la Corte de Apelaciones de Santiago de fecha 04 de mayo de 1959 en contra de Martínez Peña, por su responsabilidad en la producción de leche defectuosa ("Delicias"), o de la Sentencia de la Ilustrísima Corte de Apelaciones de San Miguel, Rol 2185-1997, de 30 de mayo de 2003, a propósito del célebre caso de las "Galletas Competa". Recientemente destaca la sentencia dictada por el Juzgado de Garantía de San Bernardo de fecha 15 de diciembre del año 2008 en causa RUC: 0800061012-8, por el delito contemplado en el artículo 314 del CP. 
SALAZAR, Andrés. "El delito de mantención de la venta de alimentos defectuosos al público: Una revisión del artículo 315 del Código Penal a partir de la teoría de las presunciones y de la dogmática de los delitos de omisión propia”.

“...[dicha] norma está construida a partir de la descripción de las conductas adulterar, vender o distribuir, claramente constitutivas de acciones y no de omisiones. Si algún tipo de comisión omisiva podría tener lugar, es aquella que los autores han entendido como impropia, pues la característica de ésta es que no incluyéndose expresamente la omisión en la descripción típica, a través de un ejercicio interpretativo se produce la vinculación de esta forma de comportamiento con el resultado previsto para la acción sí descrita (...) Sin embargo, el tipo penal del inciso segundo no describe un resultado. Sí la descripción sólo se limita a acciones no podemos entender que sea un delito de omisión propia, ya lo dijimos. Y si tampoco contempla un resultado, nos encontramos ante la imposibilidad de construir interpretativamente su comisión por omisión impropia, puesto que carecemos de una de las exigencias teóricas para lograrlo".

Esta opinión fue plenamente avalada por nuestra Corte Suprema, que señaló en la sentencia que desechó los recursos de nulidad planteados tanto por el Ministerio Público como por las partes querellantes, lo siguiente:

"...el análisis que el tribunal [de la instancia] hace es correcto, en cuanto de cara a los verbos rectores del tipo en estudio, "adulterar", "vender" y "distribuir", concluye que claramente ellos implican conductas activas no susceptibles de ser realizadas por omisión y luego se sostiene que atendido el hecho que ese precepto no está construido en relación a un resultado, no es posible en relación a ese extremo, levantar la tesis de que sea cometido por omisión...”.

A nuestro juicio, la definición que adoptan ambos tribunales, referida a una supuesta imposibilidad de castigar omisiones en el marco del artículo $315 \mathrm{CP}$ es errónea. Y el yerro que nos interesa destacar aquí proviene de la inadvertencia de una regla sustantiva que viene a complementar a las normas punitivas previstas en los dos primeros incisos de la comentada disposición: la regla a la que nos referimos es la contenida en el inc. $3^{\circ}$ del mismo precepto. No obstante, es factible pensar que la desatención constatada puede no sólo focalizarse en los tribunales que tuvieron a su cargo la misión de dirimir el citado caso, sino que, es muy probable que ella sea compartida por buena parte de los abogados que se enfrentan a la lectura del mencionado artículo. Y es que la referida inadvertencia tiene su fuente, como veremos, en una interpretación de la norma que se basa en un empleo acrítico y mecánico del término "presunción", el cual, con el correr de los años, ha adquirido un uso consolidado por parte de la profesión jurídica, proceso que tiene como consecuencia adversa el de ocultar otros sentidos que son posibles de atribuir a esa misma palabra atendiendo al especifico contexto en que ella es utilizada.

Pero antes de explicitar nuestra posición respecto del alcance que debe otorgársele a la regla del inciso tercero del artículo 315 del Código Penal, será útil apreciar los problemas interpretativos que surgen al tratar de explicar la referida disposición a partir de la función que se le asigna habitualmente a la expresión "presunción" cuando ella es empleada en contextos jurídicos. Una vez comprobada la inadecuación de dicha concepción para explicar satisfactoriamente la referida regla, se intentará abrir paso a una mejor interpretación a través de vías alternativas. 
Polít. crim. Vol. 10, № 19 (Julio 2015), Art. 11, pp. 318-361.

[http://www.politicacriminal.cl/Vol_10/n_19/Vol10N19A11.pdf]

\section{Análisis preliminar del inciso tercero del Art. 315 a partir de una posición tradicional.}

Para los efectos de retomar nuestra argumentación, creemos necesario volver a repasar los tres primeros incisos del artículo 315 del Código Penal, los cuales constituyen una parte relevante del contexto de la norma cuyo contenido se explora ${ }^{21}$. Recordemos entonces que las referidas disposiciones expresan lo siguiente:

Art. 315. El que envenenare o infectare comestibles, aguas u otras bebidas destinados al consumo público, en términos de poder provocar la muerte o grave daño para la salud, y el que a sabiendas los vendiere o distribuyere, serán penados con presidio mayor en su grado mínimo y multa de veintiuna a cincuenta unidades tributarias mensuales.

El que efectuare otras adulteraciones en dichas sustancias destinadas al consumo público, de modo que sean peligrosas para la salud por su nocividad o por el menoscabo apreciable de sus propiedades alimenticias, y el que a sabiendas las vendiere o distribuyere, serán penados con presidio menor en su grado máximo y multa de seis a cincuenta unidades tributarias mensuales.

Para los efectos de este artículo, se presumirá que la situación de vender o distribuir establecida en los incisos precedentes se configura por el hecho de tener a la venta en un lugar público los artículos alimenticios a que éstos se refieren.

Pues bien, ¿qué función le podemos asignar a la norma incluida en el tercer inciso de esta disposición?

Como señalamos, si acudimos al lenguaje técnico-jurídico, la respuesta podría ser sencilla: La norma contiene una presunción, por lo tanto, ella debería ser entendida como una regla de carácter probatorio.

Para testear esta tesis repasaremos primero, muy someramente, las características que se asignan comúnmente a las reglas probatorias de presunción. Una vez culminado dicho ejercicio podremos evaluar en concreto el rendimiento que posee una interpretación del inciso $3^{\circ}$ del artículo $315 \mathrm{CP}$ basada en estos presupuestos ${ }^{22}$.

\footnotetext{
${ }^{21}$ Siendo la interpretación un ejercicio esencialmente semántico, estimamos que la elucidación del alcance de un determinado concepto resulta ser un ejercicio eminentemente indexical, esto es, dependiente, en buena medida del contexto en que éste se inserta. En este sentido, se concuerda con Alexy en cuanto a que el contexto constituye un elemento indispensable para dilucidar si un determinado enunciado contiene o no una norma. En este orden de ideas, el mencionado autor entiende que constituye el "contexto" de un determinado enunciado "tanto los enunciados que se encuentran en conexión con este enunciado, como su uso, es decir, las circunstancias y reglas de su utilización". ALEXY, Robert, Teoría de los Derechos Fundamentales, $2^{\mathrm{a}}$ Ed., Madrid: Centro de Estudios Políticos y Constitucionales, 2008, p. 36.

${ }^{22}$ Dados nuestros fines, a pesar de reconocer su utilidad, no nos es posible emprender aquí una completa revisión de la teoría de las presunciones en el Derecho, por lo que se operará al nivel de conocimientos básicos al respecto. Para una revisión, más acabada en la materia véanse los trabajos de FRAMARINO DEI MALATESTA, Nicola, Lógica de las Pruebas en Materia Criminal, Vol. I., $4^{\mathrm{a}}$ Ed., Bogotá: Editorial Themis, 1988, pp. 175 y ss.; SILVA CANCINO, Mauricio, Las presunciones judiciales y legales, $2^{\mathrm{a}}$ Ed., Santiago: Editorial Jurídica Cono Sur, 1995. En nuestro país, una versión más actualizada de la misma puede ser revisada en VALENZUELA, Jonatan, "Presumir la responsabilidad: Sobre una relación entre la prisión preventiva y la presunción de inocencia en el Derecho Procesal Penal chileno", Revista de Estudios de la
} 
SALAZAR, Andrés. "El delito de mantención de la venta de alimentos defectuosos al público: Una revisión del artículo 315 del Código Penal a partir de la teoría de las presunciones y de la dogmática de los delitos de omisión propia”.

Como sabemos, las presunciones en Derecho usualmente tienen por finalidad facilitar la prueba de un hecho desconocido (también denominado como "hecho presumido"), el cual es inferido a partir de la acreditación de otros hechos que sí han podido ser demostrados en el correspondiente proceso judicial, a los cuales se les denomina habitualmente "hechobase" (o indicio) ${ }^{23}$. Bajo esta perspectiva, se afirma, en general, que "las presunciones legales constituyen mandatos legislativos en virtud de los cuales se ordena tener por establecido un hecho, siempre que la concurrencia de otro hecho, indicador del primero, haya sido comprobado suficientemente" o en términos más precisos, las presunciones legales serían normas que "imponen el deber de aceptar una proposición, siempre que otra proposición se encuentre debidamente probada" 24 .

Algunas presunciones (que denominamos iuris tantum o simplemente legales) tienen como efecto colateral la redistribución de los deberes probatorios en un determinado procedimiento judicial, efecto al que usualmente se le designa como "inversión de la carga de la prueba". Esta inversión tiene lugar en atención a que dichas presunciones son consideradas esencialmente derrotables, esto es, su efecto (el de dar por acreditado un hecho que se desconoce a partir de otros conocidos) permanece mientras no hayan mejores razones (antecedentes) que demuestren lo contrario.

Además de las descritas, existe un segundo tipo de presunciones: las de derecho o iure et de iure. Éstas, en términos estrictos, no invierten la carga de la prueba, sino que, muy por el contrario, (por decisión del legislador) declaran institucionalmente acreditado el hecho desconocido una vez probado el hecho base que la sustenta, sin que se admita respecto de ello prueba en contrario. La fuerza que posee este tipo de reglas ha llevado a limitar su validez en el Derecho Penal, siendo ilegitimo el establecimiento de presunciones de derecho que se refieran a la responsabilidad penal (culpabilidad de un determinado agente). La distinción entre presunciones de derecho y simplemente legales tiene reconocimiento positivo en nuestro país a través del artículo 44 del Código Civil ${ }^{25}$. Sin embargo, hoy en día la "prueba por presunciones" tiene una importancia relativa en los distintos subsistemas jurídicos que componen el Derecho chileno. En efecto, en el contexto del derecho procesal civil, que aún se basa en el principio de prueba legal o tasada, las presunciones mantienen

Justicia, No 14 (2011), pp. 53-69; EL MISMO, “Inocencia y Razonamiento Probatorio", Revista de Estudios de la Justicia, № 18 (2013), pp. 13-22.

${ }^{23} \mathrm{Y}$ es que tal y como destaca Valenzuela, citando Nieva Ferrel: "Todas las presunciones parecen responder a la siguiente estructura: "a) Un hecho presunto: lo sospechado o conjeturado; b) Un hecho base: los indicios o señales; c) Una conexión entre ellos. La conexión entre el hecho base y el hecho presunto presupone una regla de presunción; es decir, un enunciado general cuya aceptación autoriza el paso de uno a otro hecho". VALENZUELA, "Inocencia y Razonamiento Probatorio", cit. nota n 22, p. 14.

${ }^{24}$ MENDOCA, Daniel, Las claves del derecho, Barcelona: Editorial Gedisa, 2008, pp. 219 y 220.

${ }^{25}$ Art. 47. Se dice presumirse el hecho que se deduce de ciertos antecedentes o circunstancias conocidas. $\mathrm{Si}$ estos antecedentes o circunstancias que dan motivo a la presunción son determinados por la ley, la presunción se llama legal.

Se permitirá probar la no existencia del hecho que legalmente se presume, aunque sean ciertos los antecedentes o circunstancias de que lo infiere la ley; a menos que la ley misma rechace expresamente esta prueba, supuestos los antecedentes o circunstancias.

Si una cosa, según la expresión de la ley, se presume de derecho, se entiende que es inadmisible la prueba contraria, supuestos los antecedentes o circunstancias. 
Polít. crim. Vol. 10, № 19 (Julio 2015), Art. 11, pp. 318-361.

[http://www.politicacriminal.cl/Vol_10/n_19/Vol10N19A11.pdf]

gran importancia a la hora de acreditar hechos controvertidos, influir en el razonamiento judicial y la conformación del grado de convicción exigido por dicho sistema. Por su parte, con la importante salvedad de la presunción de inocencia, el mencionado mecanismo legal se ve fuertemente devaluado en el proceso penal dado que dicho sistema se encuentra construido sobre la base del principio de libertad probatoria. De hecho, en dicho contexto, hoy se suele hablar más bien de la importancia de la prueba indiciaria ("presunciones judiciales") que de la prueba por presunciones.

Finalmente, como se verá más adelante, para nuestros efectos resulta importante destacar que de acuerdo a la doctrina comparada, a nivel lógico, la forma más aceptada de formular la estructura de una regla probatoria de presunción es la que se grafica a continuación: "PRES (P, Q)"'26.

Bajo esta formulación, el operador "PRES" designa la presunción, mientras que "P" configura el hecho base acreditado. Por su parte, el hecho presumido es " $Q$ ". En concreto, la formula se podría leer de la siguiente manera: "existe la presunción, a partir de $\mathrm{P}$ que Q"27.

Nos encontramos ahora en condiciones de interpretar la regla del inciso $3^{\circ}$ del artículo 315 $\mathrm{CP}$, a la luz de la doctrina tradicional de las presunciones probatorias. Veamos, entonces, qué encontramos en esta norma.

Como vimos la regla indica que "[p]ara los efectos de este artículo, se presumirá que la situación de vender o distribuir establecida en los incisos precedentes se configura por el hecho de tener a la venta en un lugar público los artículos alimenticios a que éstos se refieren".

Utilizando el aparato conceptual ya revisado, deberíamos estar de acuerdo en que existiría un hecho-base o indicador que permitiría acreditar dos hechos presumidos distintos; en concreto, la regla nos diría que si somos capaces de acreditar el hecho-base "tener a la venta en un lugar público el producto deteriorado", por disposición de la ley, el juez debería dar por acreditado el hecho presumido (1) "situación de vender" o el hecho presumido (2) "situación de distribuir" el alimento defectuoso.

Pues bien, comencemos con la relación entre el hecho-base "mantener a la venta en un lugar público el alimento envenenado, infectado, adulterado o deteriorado" y el hecho presumido "vender el alimento envenenado, infectado, adulterado o deteriorado".

Lo primero que podemos notar es que una regla como ésta se encuentra sometida a una ambigüedad relevante que se deriva de la utilización del término "vender". Y es que, tal

\footnotetext{
${ }^{26}$ Esta formulación se la debemos a Edna Ullmann-Margalit, Se ha decidido resaltar la forma en que se denotan lógicamente las presunciones como reglas probatorias ya que como se verá más adelante, existen importantes diferencias con la formulación lógica de las presunciones entendidas como reglas constitutivas. Esta formulación es citada por MENDOCA, "Presunciones", DOXA N 21 (1998), p. 86.

${ }^{27}$ MENDOCA, "Presunciones", cit. nota $\mathrm{n}^{\circ} 26$.
} 
SALAZAR, Andrés. "El delito de mantención de la venta de alimentos defectuosos al público: Una revisión del artículo 315 del Código Penal a partir de la teoría de las presunciones y de la dogmática de los delitos de omisión propia”.

como lo indica el diccionario de la Real Academia de la Lengua Española, en un contexto como éste el verbo "vender" puede hacer referencia a dos cuestiones distintas.

Así, en un primer sentido posible, utilizamos el verbo "vender" para hacer alusión a un acto concreto de compraventa, o sea, a través de esta expresión podríamos querer hacer referencia al acto de "traspasar a alguien, por el precio convenido, la propiedad de lo que uno posee".

Por otra parte, empleamos dicha noción cada vez que deseamos hacer referencia a la actividad de "exponer $u$ ofrecer al público los géneros o mercancías para quien las quiera comprar". En otras palabras, bajo ciertas condiciones, es posible utilizar adecuadamente dicho término para referirnos al proceso o la circunstancia (genérica) de vender.

Entonces, la interpretación de la regla de presunción dependerá en gran medida del concepto que adquiera el verbo "vender" en el contexto de los incisos primero y segundo, ya que como vimos ese sería el hecho desconocido o presumido cuya prueba se pretendería facilitar a través de la norma en estudio.

Así las cosas, si entendemos que el legislador utilizó el verbo "vender" en los incisos primero y segundo del artículo $315 \mathrm{CP}$ para referirse a actos concretos de compraventa, la regla probatoria que aparentemente se encontraría en el inciso tercero podría leerse de la siguiente forma:

(a) "Para dar por probada la venta (i.e. compraventa) de alimentos envenados, infectados, adulterados o disminuidos en sus propiedades nutricionales bastará con acreditar que los alimentos envenados, infectados, adulterados o disminuidos en sus propiedades nutricionales están siendo ofrecidos a potenciales consumidores (i.e vendidos.) en un lugar público, salvo prueba en contrario".

Así entendida, al menos a primera vista, la regla de que se trata parece conformarse plenamente con la estructura de una presunción probatoria de acuerdo a lo expuesto más arriba. En efecto, una lectura descontextualizada del inciso tercero podría hacernos pensar que no hay nada de malo en una presunción como ésta; y es que, efectivamente, del hecho conocido "ofrecer el producto en un lugar público" podría inferirse perfectamente el hecho desconocido "se realizaron actos de entrega de alimentos defectuosos a cambio de dinero", en el local comercial de que se trata.

Sin embargo, leída en el contexto normativo en el que se inserta, una presunción como ésta deviene en contradictoria con el resto de la disposición legal. Y esto es así, porque no podemos olvidar que, tal y como anticipamos, los delitos de los incisos primero y segundo del artículo $315 \mathrm{CP}$ son delitos de peligro abstracto.

Que éstos sean considerados delitos de peligro abstracto implica que el legislador ha estimado que, para que opere la sanción asignada a ellos, no se requiere que bien jurídicopenal individual alguno (salud o vida de las personas, en nuestro caso) entre en contacto (concretamente) con la situación de riesgo generada por el agente (sea éste el productor, 
Polít. crim. Vol. 10, № 19 (Julio 2015), Art. 11, pp. 318-361.

[http://www.politicacriminal.cl/Vol_10/n_19/Vol10N19A11.pdf]

distribuidor o vendedor del producto nocivo), sino que basta que el alimento defectuoso se encuentre en alguna de las etapas productivas descritas, debido a que se entiende que dicho estado de cosas, por sí mismo, resulta lesivo para el bien jurídico colectivo salud pública ${ }^{28}$. La anterior afirmación se ve confirmada tanto por el texto legal como por la historia legislativa del precepto.

En efecto, en primer lugar, basta con advertir que la mera producción de alimentos nocivos ya se encuentra sancionada, y esto es signo inequívoco de que el legislador no pretendió condicionar la aplicación de la pena dispuesta para este ilícito a la provocación de un riesgo concreto para la salud individual de los eventuales consumidores.

En segundo lugar, debe destacarse que los parlamentarios que intervinieron en la redacción del actual artículo 315 del CP fueron extraordinariamente conscientes del hecho de estar creando un delito de peligro abstracto a través de la presente disposición, tanto es así que manifestaron explícitamente su voluntad de crear un ilícito de tales características ${ }^{29}$.

\footnotetext{
${ }^{28}$ Acerca de las relaciones que son posibles de trazar entre delitos de peligro abstracto y tipos penales destinados a proteger bienes jurídico colectivos, véase CORCOY BIDASOLO, Mirentxu, Delitos de Peligro y Protección de Bienes Jurídicos Supraindividuales. Nuevas formas de delincuencia y reinterpetación de tipos penales clásicos, Valencia: Editorial Tirant Lo Blanch, 1999; KINDHÄUSER, Urs, "Estructura y legitimación de los delitos de peligro del Derecho Penal", Trad. PASTOR MÚÑOZ, Nuria, en: KINDHÄUSER, Urs, Teoría de las normas y sistemática del delito, Lima: Ara Editores, 2008, pp. 39-61; HEFENDEL, Roland, "¿Debe ocuparse el Derecho Penal de Riesgos Futuros? Bienes jurídicos colectivos y delitos de peligro abstracto", Revista Electrónica de Ciencia Penal y Criminología no 4 (2002), en: http://criminet.ugr.es/recpc/recpc 04-14.pdf; En nuestro país, VARGAS, Tatiana, Delitos de Peligro Abstracto y Resultado. Determinación de la incertidumbre penalmente relevante, Pamplona: Editorial Aranzadi, 2007; desde una concepción tradicional de los delitos de peligro CURY, Enrique, Derecho Penal,

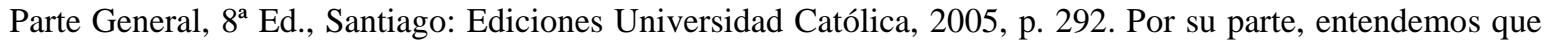
bajo la terminología empleada por Maldonado, los comportamientos típicos incluidos en la norma de sanción del artículo 315 CP deberían ser considerados como de "peligrosidad" ya que el envenenamiento, infección o adulteración de bebidas o comestibles resulta ser una condición de idoneidad que permite fundamentar, a través de un juicio de peligrosidad ex-ante la objetiva idoneidad o potencialidad lesiva de los alimentos producidos, distribuidos o vendidos, tanto para la salud pública como bien jurídico colectivo (en tanto, entendida ésta como seguridad en el consumo) como para la salud individual de los potenciales consumidores. Al respecto MALDONADO, Francisco, "Reflexiones sobre las técnicas de tipificación de los llamados "delitos de peligro" en el moderno Derecho Penal", Revista de Estudios de la Justicia n 7 (2006), pp. 33 y ss.

${ }^{29}$ Al respecto, extremadamente clarificadora se demuestra la discusión que tuvo lugar en la Cámara de Diputados en la $25^{\text {a }}$ Sesión del día martes 8 de Abril de 1969, a propósito de la redacción definitiva que debería adoptar la citada disposición. En dicha instancia los parlamentarios debatieron respecto a cuál podría ser la mejor redacción para el actual artículo 315 CP y dicha definición giraba en torno a dos alternativas posibles: En pugna se encontraban la propuesta realizada por la cámara baja y el texto ideado por el Senado, que es el que, en definitiva, resultó aprobado por el parlamento. En este contexto y luego de un debate al respecto, fueron las consideraciones expuestas por el H. Diputado Sr. Tejada las que primaron y que permitieron que se impusiera la formulación propuesta por la cámara alta. En dicha intervención el citado legislador argumentó lo siguiente: “...el artículo de la Cámara castiga sólo en el caso de que se expendan o distribuyan sustancias alimenticias inaptas, descompuestas, infectadas, envenenadas, etcétera; en cambio, el artículo del Senado aplica la sanción aunque no haya expendio, aunque no se distribuya, por el sólo hecho de envenenar o infectar los comestibles aguas u otras bebidas destinadas al consumo público, aunque no se usen, repito, siempre se castiga (...) además, castiga por el sólo hecho de envenenar las aguas o infectar los comestibles, aun cuando no se hayan expendido". Creemos que no es posible ofrecer mejor prueba de la voluntad legislativa al respecto.
} 
SALAZAR, Andrés. "El delito de mantención de la venta de alimentos defectuosos al público: Una revisión del artículo 315 del Código Penal a partir de la teoría de las presunciones y de la dogmática de los delitos de omisión propia”.

Entonces, sentado el hecho de que los incisos primero y segundo consagran delitos de peligro abstracto, la presunción ubicada en el inciso tercero (al menos en los términos hasta aquí estudiados) deviene en una regla inútil e injustificada. Y es que, ¿qué sentido tendría el establecer una presunción que permite dar por acreditada la existencia de compraventas de alimentos nocivos, cuando el mismo legislador no ha pretendido exigir para el castigo de estos delitos que el producto llegue a manos de los consumidores (esto es, que la cosa sea efectivamente vendida a alguna persona)?. En otras palabras, a través de una presunción como ésta se estaría logrando probar una circunstancia no exigida por el tipo penal y, por lo tanto, se trataría de una prueba sobreabundante o, al menos impertinente, produciéndose, entonces, una situación similar a la prevista por la regla contenida en el inc. $2^{\circ}$ del art. 276 $\mathrm{CPP}$, que impone al juez de garantía la obligación de excluir del proceso penal antecedentes "probatorios" de ese tipo.

Por lo tanto, una interpretación como ésta debe ser rechazada pues conduce a un resultado absurdo.

De esta forma, todo parecería indicar que resultaría mucho más coherente con la estructura de la citada norma entender que el legislador utilizó la palabra "vender", en todos los incisos del artículo $315 \mathrm{CP}$, comprendiéndola como el proceso o a la actividad de "exponer u ofrecer al público géneros o mercancías".

Si esto es así, entonces, nos corresponde interpretar la regla del inciso tercero como presunción probatoria, donde los incisos primero y segundo contendrían el hechopresumido "ofrecer el producto nocivo a la venta", mientras que el mencionado inciso tercero contendría el hecho-base "ofrecer el producto nocivo a la venta".

Esto, a primera vista, nos parece llevar a una especie tautología dada la circularidad (autorreferencialidad) que parece adoptar un precepto así entendido. Esta característica resulta notoria debido a que, de acuerdo con lo expuesto más arriba, la norma del inciso tercero puede ser leída de la siguiente forma:

(b) "para acreditar que el agente vende (ofrece al público) el producto defectuoso Ud. debe acreditar que se vende (ofrece al público) el producto defectuoso, salvo prueba en contrario".

No obstante, en dichos términos, la regla probatoria (al menos para la hipótesis de vender) aparecería como superflua e inútil ya que el hecho base coincidiría plenamente con el hecho presumido. El problema de esta caracterización de la regla es que, como sabemos, las tautologías son enunciados carentes de sentido ya que siempre, en todos los casos y bajo todas las condiciones posibles, son verdaderos ${ }^{30}$.

\footnotetext{
${ }^{30}$ En este sentido, Wittgenstein explica que: "Entre los grupos posibles de condiciones veritativas hay dos casos extremos. En uno de ellos la proposición es verdadera para todas las posibilidades veritativas de las proposiciones elementales. Decimos que las condiciones veritativas son tautológicas. En el segundo, la proposición es falsa para todas las posibilidades veritativas: las condiciones veritativas son contradictorias. En el primer caso llamamos a la proposición una tautología, en el segundo una contradicción... La proposición muestra lo que dice. La tautología y la contradicción, que no dicen nada. La tautología carece de posibilidades
} 
Polít. crim. Vol. 10, № 19 (Julio 2015), Art. 11, pp. 318-361.

[http://www.politicacriminal.cl/Vol_10/n_19/Vol10N19A11.pdf]

Al mismo tiempo, en términos pragmáticos, una norma como ésta no presta ninguna utilidad a la dialéctica probatoria del proceso penal, ya que debe reconocerse que quien prueba el hecho base de "vender en un lugar abierto al público" el alimento nocivo prueba al mismo tiempo (y sobre la base de los mismos antecedentes) que el alimento nocivo está siendo vendido, circunstancia que, se supone, constituye el hecho desconocido cuya acreditación pretendería facilitar dicha presunción.

En otras palabras, ¿de qué nos sirve una regla de presunción en donde el hecho desconocido o presumido es idéntico al hecho-base o indicio? Una lectura como ésta transformaría a la regla del inciso $3^{\circ}$ en irrelevante.

Para finalizar hemos dejado el análisis de la supuesta relación existente entre el hecho base "mantener a la venta en un lugar público" y el hecho presumido "situación de distribuir". Sobre este punto, luego de un breve razonamiento, resulta evidente la inutilidad de un precepto probatorio dirigido en ese sentido. Ello es así porque una regla como esa lo único que haría sería consagrar una inferencia trivial por su obviedad ${ }^{31}$.

De este modo, creemos haber demostrado que la regla contenida en el inciso tercero del artículo 315 del CP, a pesar de utilizar la expresión presunción, no funciona como la regla probatoria que podría pensarse que es.

Sin embargo, antes de apresurarnos a declarar la total inutilidad del precepto, quisiera intentar una explicación alternativa de la regla, acudiendo a un sentido distinto que puede asignársele al uso de la expresión presunción en el Derecho. A la verificación de esta tesis alternativa se dedican las siguientes páginas.

\section{Interpretación alternativa de la voz "presunción" utilizada en el inc. $3^{\circ}$ del Artículo 315 del Código Penal. Las presunciones como reglas constitutivas.}

Sentada la imposibilidad de entender la norma del inciso $3^{\circ}$ del artículo 315 como una regla probatoria de presunción, a nuestro juicio, sólo queda una posibilidad de entenderla de

veritativas porque es incondicionalmente verdadera (...) tautología y contradicción carecen de sentido (...) no son figuras de la realidad. No representan ningún posible estado de cosas (...) en la tautología las condiciones de coincidencia con el mundo - las relaciones representativas- se neutralizan entre sí, de modo que no está en relación representativa alguna con la realidad...". WITTGENSTEIN, Ludwig, Tractatus Logicophilosophicus, Madrid: Alianza Editorial, 2003, ( $\S 4.46-4.462)$, pp. 84 y 85.

${ }^{31}$ En efecto, existirían dos posibles situaciones cubiertas por una regla como ésta: (a) o el productor es la misma persona que vende el alimento defectuoso o (b) productor, distribuidor y vendedor son personas distintas. De esta forma, en la primera hipótesis, o (a1) no habría distribución alguna o (a2) la distribución sería irrelevante en términos probatorios para el arribo a una conclusión condenatoria (en atención a que sería el mismo productor el que se encargó de transportar el alimento nocivo a uno o varios locales de venta que también le pertenecen). Y es que, esto es así, desde el momento en que se tiene en cuenta que basta con acreditar la mera elaboración del alimento defectuoso para que proceda el castigo del agente que realiza todas las etapas productivas por su propia cuenta. Por su parte, la segunda hipótesis conduce a una inferencia trivial que cualquier persona puede realizar sin necesidad alguna de una regla de razonamiento explicita que lo guíe al respecto. En efecto, resulta obvio que si el producto defectuoso llegó a ser vendido por una persona (natural o jurídica) distinta de aquella que la produjo, ese mismo alimento debió haber sido trasladado desde el punto de producción hasta el punto de venta. 
SALAZAR, Andrés. "El delito de mantención de la venta de alimentos defectuosos al público: Una revisión del artículo 315 del Código Penal a partir de la teoría de las presunciones y de la dogmática de los delitos de omisión propia".

forma coherente con el resto de la disposición en la que ella se encuentra inserta. Anticipando la conclusión a la que llegaremos, creo que es posible afirmar que ésta se trata de una regla constitutiva, cuyo efecto, como se verá más adelante, consiste en el de tipificar (y sancionar penalmente) la conducta de mantener a la venta alimentos nocivos, a pesar de conocer el defecto que dicho producto padece.

Sin embargo, antes de desarrollar en profundidad la conclusión que se adelanta, deberemos justificar dicha inferencia. Para ello el primer paso que debemos dar es el de repasar el concepto y la función que poseen las reglas constitutivas en el Derecho.

\subsection{Acerca de las reglas constitutivas.}

La noción de "reglas constitutivas" fue incorporada por el filosofo norteamericano John Searle, quien, a su vez, desprendió dicho concepto de la teoría de los actos de habla iniciada por John L. Austin.

Los estudios de Austin confrontaron a la visión filosófica dominante en su época, la cual entendía al lenguaje como un instrumento comunicativo meramente informativo. De acuerdo con aquella posición, los filósofos entendían que, básicamente, la función (casi exclusiva) que se le podía atribuir al lenguaje era la de comunicar, trasmitir información acerca del mundo a través de enunciados descriptivos, enunciados que, por lo tanto, eran susceptibles de ser calificados como verdaderos o falsos. Bajo este paradigma, prácticamente todo lo que no era susceptible de ser calificado como verdadero o falso era rotulado como un sinsentido.

Austin, por su parte, demostró la existencia de cierta clase de enunciados que no siendo susceptibles de verificación, tampoco pueden ser calificados como un sinsentido. Estos enunciados (proferidos bajo ciertas condiciones) implicaban la realización de actos, no de descripciones. Así por ejemplo, cuando alguien pronuncia las palabras "yo prometo" realiza la acción de prometer y la consecuencia directa de pronunciar esas palabras es la de contraer (voluntariamente) una obligación con otro. También, en el contexto adecuado (una ceremonia matrimonial), al pronunciar las palabras "sí, acepto" una persona puede contraer matrimonio, válidamente, ante el Estado. Austin denominó a éstos enunciados realizativos o performativos esgrimiendo que su nombre "deriva, por supuesto, de realizar, (...) indica que emitir [esa] expresión es realizar una acción"32; esto quiere decir, en otros términos, que "si una persona hace una emisión de este tipo diríamos que está haciendo algo, en vez de meramente diciendo algo"33.

Searle, por su parte, perfeccionó la teoría de los actos de habla iniciada por Austin. Este autor, partió de la premisa de que "hablar un lenguaje es participar en una forma de conducta gobernada por reglas", o sea, en palabras simples, "hablar consiste en realizar

\footnotetext{
${ }^{32}$ AUSTIN, John L., Cómo Hacer Cosas con Palabras. Barcelona: Editorial Paidos, $2^{\text {a }}$ Ed., 2003, p. 47.

${ }^{33}$ AUSTIN, John L., "Emisiones realizativas", en: VALDÉS VILLANUEVA, Luís (Comp.), La Búsqueda del Significado, Madrid: Editorial Tecnos, 2005, p. 417.
} 
Polít. crim. Vol. 10, № 19 (Julio 2015), Art. 11, pp. 318-361.

[http://www.politicacriminal.cl/Vol_10/n_19/Vol10N19A11.pdf]

actos conforme a reglas" ${ }^{34}$. En lo que a nosotros concierne, nos interesa una categorización de reglas introducidas por Searle a propósito del desarrollo de su teoría de los actos de habla. Nos referimos a la distinción entre "reglas regulativas" y "reglas constitutivas",35. Según Searle:

"las reglas regulativas regulan formas de conducta existentes independientemente o antecedentemente (...) [p] ero las reglas constitutivas no regulan meramente: crean o definen nuevas normas de conducta... Las reglas regulativas regulan una actividad prexistente. Las reglas constitutivas constituyen (y también regulan) una actividad cuya existencia lógica es dependiente de las reglas..."36.

En este orden de ideas el profesor norteamericano indica que:

"El ejemplo clásico son las normas del ajedrez (...) la posibilidad misma de jugar al ajedrez depende de que existan normas de ajedrez, porque jugar al ajedrez consiste en actuar de acuerdo con, como mínimo, cierto subconjunto bastante amplio de reglas de ajedrez". Así las cosas "[1] as normas constitutivas también regulan, pero hacen algo más que regular: tal como he sugerido, constituyen la actividad misma que regulan ${ }^{37,}$.

La noción de reglas constitutivas, como el lector podrá anticipar, resulta esencial para entender la cultura y las instituciones en las que basamos la vida moderna. De hecho, reglas de este tipo son las que permiten entender lo que Searle denomina "hechos institucionales". Así, ejemplificando, el dinero, el matrimonio, la nacionalidad, de la ciudadanía o la propiedad sólo pueden existir dentro de sistemas de reglas constitutivas.

En otras palabras, las reglas constitutivas poseen efectos performativos, crean realidades que sin ellas no existirían.

No nos es posible en el poco espacio del que disponemos seguir profundizando en la filosofía de Austin y Searle ${ }^{38}$. Ello conspiraría además contra el objetivo que nos hemos

\footnotetext{
${ }^{34}$ SEARLE, John, Actos de Habla, Madrid: Editorial Cátedra. $6{ }^{a}$ Ed., 2007, p. 31; Un punto de partida similar es el que utiliza el "segundo" Wittgenstein para fundamentar su filosofía del lenguaje, sustentándola sobre la base de la noción de "juegos de lenguaje". A este respecto, WITTGENSTEIN, Ludwig, Investigaciones Filosóficas, Barcelona: Editorial Crítica, 2008, pp. 39-43, §§ 23 y ss.

${ }^{35}$ SEARLE, Actos, cit. nota ${ }^{\circ}$ 34, pp. 42-51; EL MISMO, La Construcción de la Realidad Social, Barcelona: Editorial Paidos, 1997, pp. 49-74; EL MISMO, Mente, Lenguaje y Sociedad, Madrid: Editorial Alianza, 2004, pp.103-122.

${ }^{36}$ SEARLE, Actos, cit. nota n ${ }^{\circ} 34$, pp. $42-43$.

${ }^{37}$ SEARLE, Mente, cit. nota ${ }^{\circ}$ 35, p. 113.

${ }^{38}$ Así por ejemplo, podríamos mencionar que luego de introducir la distinción entre enunciados constatativos (descriptivos) y enunciados realizativos (performativos), Austin pudo apreciar que quien emite un enunciado constatativo al mismo tiempo realiza el acto de habla de afirmar (por ejemplo, "llueve"), tras lo cual disolvió la diferencia que trazó entre enunciados realizativos y enunciados constitutivos, para dar paso a la importante noción filosófica de "actos ilocutivos" que será desarrollada con mayor precisión, posteriormente, por Searle. No obstante, creo junto con Reig, que la distinción entre enunciados constativos y realizativos (o performativos) mantiene su importancia a nivel lingüístico, dado que entre ambos tipos de enunciados (por ejemplo "llueve" -descriptivo- versus "prometo que iré" -realizativo-) "conservan una diferencia importante para la teoría de los actos del habla" así por ejemplo mientras que al emitir la promesa de que iré "se realiza el acto ilocutivo que se dice que se realiza" (promesa) "al emitir "llueve" se realiza el acto de aseverar sin
} 
SALAZAR, Andrés. "El delito de mantención de la venta de alimentos defectuosos al público: Una revisión del artículo 315 del Código Penal a partir de la teoría de las presunciones y de la dogmática de los delitos de omisión propia”.

trazado como meta al iniciar el presente artículo. Sin embargo, antes de culminar, quisiéramos destacar dos características adicionales de las reglas constitutivas que serán de gran utilidad para nuestro posterior análisis.

En primer lugar, cabe detenerse en la formulación lógica de las reglas constitutivas. De acuerdo con Searle, las normas constitutivas poseen la siguiente forma que le es característica:

"X cuenta como Y en el contexto C".

A través de esta formulación puede analizarse por ejemplo la siguiente oración:

"Los billetes emitidos por el Bureau of Engraving and Printing (X) cuentan como dinero (Y) en los Estados Unidos (C)”.

Nótese que esta forma lógica demuestra que sea quién sea el que impone la regla constitutiva, al establecerla, determina relaciones de equivalencia entre dos entidades o conceptos, en un determinado y específico contexto (en nuestro ejemplo: los billetes emitidos por dicha agencia estatal equivalen a dinero en ese país).

Para finalizar, quisiéramos resaltar un último pasaje de los estudios del profesor Searle en relación con las características que poseen este tipo de reglas (por contrapartida de las reglas regulativas); nos referimos a su carácter (cuasi) tautológico:

"Las reglas regulativas toman característicamente la forma de, o pueden ser parafraseadas como, imperativos(...) [Por su parte], [a]lgunas reglas constitutivas toman una forma totalmente diferente; (...) tales reglas constitutivas (..) probablemente nos sorprenderán como extremadamente curiosas y difícilmente las reconoceremos incluso como reglas en absoluto. Obsérvese que tienen un carácter casi tautológico, pues lo que la regla parece ofrecer es parte de una definición...”39.

En la actualidad, muchos teóricos contemporáneos del Derecho han reconocido en la noción de reglas constitutivas un concepto de gran rendimiento y potencialidad a la hora de explicar el fenómeno jurídico. Así por ejemplo, siguiendo a Neil MacCormick, la noción de reglas constitutivas resulta útil para entender por qué el trozo de metal que tengo en mí mano cuenta como moneda en nuestro mercado y me permite realizar actividades transaccionales, sin temor a que alguna persona que ofrece determinados bienes de

decir que se está aseverando". En este sentido, "para la lingüística resulta interesante el hecho de que en (¿todas?) las lenguas existen enunciados que tienen esta propiedad, que podemos llamar realizatividad, que distingue" a una aseveración de una promesa, por ejemplo. Y es que "cuando el enunciado tiene la propiedad de ser realizativo, su emisión supone inmediatamente realizar el acto elocutivo nombrado en este enunciado". REIG, Assela, "Una clasificación de los verbos realizativos en Español", en: FACE, Timothy y KLEE, Carol, Selected proceeedings of the $8^{\text {th }}$ Hispanic Linguistics Symposim. USA: Cascadilla Proceeding Project, 2006, pp. 183-190. En otras palabras, los enunciados realizativos poseen la característica de ser autorreferenciales, ser reflexivos, de manera que su enunciación comparte en buena medida la circularidad que se da en las tautologías.

${ }^{39}$ SEARLE, Actos, cit. nota ${ }^{\circ} 34$, p. 43. Lo escrito entre corchetes es nuestro. 
Polít. crim. Vol. 10, № 19 (Julio 2015), Art. 11, pp. 318-361.

[http://www.politicacriminal.cl/Vol_10/n_19/Vol10N19A11.pdf]

consumo en ese mismo mercado, no acepte dicho círculo metálico como medio de pago válido para adquirirlos. Esto sólo es posible, gracias a la existencia de reglas constitutivas que crean hechos institucionales como el sistema monetario. La misma idea se puede aplicar a otros contextos de la vida humana, donde la posibilidad de actuación en ellos depende necesariamente de reglas que creen estos escenarios artificiales para el desenvolvimiento humano. Piense por ejemplo, en la posibilidad que tanto Ud. como yo tenemos de acudir al mercado de valores, espacio en el cual, garantizadas legalmente ciertas condiciones mínimas de transparencia y confianza, podemos transar acciones o instrumentos derivados. Esta realidad sólo es posible gracias a este tipo de reglas ${ }^{40}$.

Finalmente, tal y como advierte Schauer $^{41}$, no debe perderse de vista que las reglas constitutivas, de todas formas, mantienen siempre un carácter regulativo. En palabras de este autor, "[1]a regla [constitutiva] tiene un doble aspecto: primero define la conducta y luego la regula". Así por ejemplo, las reglas del fútbol que definen lo que debe entenderse por un foul (golpear a un jugador desde atrás, por ejemplo) prohíben, al mismo tiempo (y bajo sanción) la comisión de las conductas definidas anticipadamente como fouls". No obstante dicha constatación, Schauer no pone en cuestión la utilidad de la distinción entre reglas regulativas y reglas constitutivas, debido a que si bien puede pensarse que toda regla tiene un contenido regulativo (de mayor o menor intensidad) no toda regla tiene el potencial performativo que se encuentra adscrito a las reglas constitutivas.

Habiendo visto entonces algunas nociones de lo que son las reglas constitutivas para la filosofía del lenguaje, estamos en condiciones de continuar con nuestra argumentación.

\subsection{Las presunciones como reglas constitutivas de acuerdo con la Filosofía del Derecho contemporánea.}

En la actualidad, el concepto de presunción está siendo sometido a una profunda revisión por parte de la dogmática jurídica.

La principal causa de los cuestionamientos que se dirigen contra la concepción tradicional de las presunciones, reside en la constatación, realizada por un importante número de teóricos del derecho, de que aquella noción se encuentra aquejada de una importante ambigüedad $^{42}$. De acuerdo con estos autores, se ha podido apreciar que a través del uso del término "presunción" la doctrina estándar ha tratado de cubrir fenómenos normativos muy

\footnotetext{
${ }^{40}$ Así, por ejemplo un tipo muy importante de reglas constitutivas son las definiciones legales. Cuando el Código Civil define lo que es el contrato de mandato o el derecho de servidumbre, no podemos afirmar que esos enunciados jurídicos puedan ser susceptibles de ser calificados como verdaderos o falsos. Simplemente crean realidades, definen conceptos y sirven de apoyo o permiten regular conductas a través de reglas regulativas de forma menos compleja que si aquéllas no existieran. Sobre esto HERNÁNDEZ MARÍN, Rafael, Introducción a la Teoría de la Norma Jurídica, $2^{\mathrm{a}}$ Ed., Madrid: Marcial Pons, pp. 259-275; 301-304. Cabe hacer presente que Hernández prefiere denominar a las reglas constitutivas como enunciados cualificatorios.

${ }^{41}$ SCHAUER, Frederic, Las Reglas en Juego, Madrid: Editorial Marcial Pons, 2004, p. 63.

42 En este sentido, GAMA, Raymundo, "Concepciones y tipología de las presunciones en el Derecho continental”, Revista de Estudios de la Justicia. Nº 19 (2013), p. 66 y ss.
} 
SALAZAR, Andrés. "El delito de mantención de la venta de alimentos defectuosos al público: Una revisión del artículo 315 del Código Penal a partir de la teoría de las presunciones y de la dogmática de los delitos de omisión propia”.

diversos y cuya agrupación en un concepto unitario aparece como forzosa e impide asignarle un tratamiento adecuado a cada una de esas heterogéneas realidades ${ }^{43}$.

No podremos hacernos cargo aquí de la totalidad de los argumentos que se han esgrimido contra la concepción tradicional de las presunciones y menos abocarnos al análisis de los posibles impactos que las nuevas propuestas teóricas podrían traer aparejadas en los distintos ámbitos del sistema jurídico. Ello nos alejaría en demasía del problema que se ha querido abordar en el presente estudio. En lo que a nosotros respecta, bastará con destacar algunos aspectos de estas nuevas concepciones, ya que ellas nos permitirán entender de mejor manera el verdadero contenido deóntico de la regla del inciso $3^{\circ}$ del artículo 315 del CP.

En particular, nos interesa repasar dos aspectos que han sido puestos de relieve por quienes defienden esta nueva forma de concebir las presunciones en el Derecho y que se encuentran relacionados entre sí.

En primer lugar, debe destacarse el hecho de que la concepción tradicional, al enfatizar el contenido instrumental-probatorio que le asigna típicamente a las normas de presunción, ha pasado por alto la circunstancia de que muchas presunciones legales no tienen por finalidad enlazar hechos (base) con hechos (presumidos) sino que, en ocasiones, ellas simplemente enlazan hechos con consecuencias jurídicas. Así, por ejemplo, el profesor Raymundo Gama ha afirmado que:

"un gran número de presunciones legales no responden a la estructura de hecho base hecho presumido. Dos ejemplos paradigmáticos son la presunción de inocencia y la presunción de buena fe. En este tipo de reglas no se exige la prueba de un hecho base como requisito para que opere la presunción..."44.

A partir de estas consideraciones, el blanco principal de las críticas propugnadas por quienes adscriben a una concepción plural de las presunciones lo constituyen las denominadas "presunciones iure et de iure". De hecho, la doctrina tradicional ya había observado la dificultad que este tipo de normas imponía a la pretensión de manejar un concepto común de presunción. Así las cosas, usualmente se esgrimía que dichas presunciones no formaban parte del derecho procesal probatorio y que en propiedad, debían ser entendidas como pertenecientes al derecho sustantivo ${ }^{45}{ }_{-}{ }^{6}$.

\footnotetext{
${ }^{43}$ De hecho, ha sido la pretensión de otorgar un tratamiento unitario al fenómeno de las presunciones jurídicas lo que ha llevado a muchos autores a denunciar la presencia de "falsas presunciones" en distintos cuerpos legales. Por su parte, quienes sostienen las contemporáneas posturas críticas respecto del uso que tradicionalmente se le ha asignado a este tipo de reglas, esgrimen que afirmaciones como ésta demostrarían que la doctrina estándar de las presunciones, a pesar de su arraigo en la cultura jurídica, no ha sido capaz de comprender a cabalidad la complejidad del problema.

${ }^{44}$ GAMA, "Concepciones", cit. nota ${ }^{\circ}$ 42, pp. 74-75.

45 GAMA, "Concepciones", cit. nota $\mathrm{n}^{\circ} 42, \mathrm{p} .76$.

${ }^{46}$ Así por ejemplo, el hecho de que no existan posibilidades de desactivar la aplicación de una presunción de derecho, por medio de la producción de prueba en contrario, podría considerarse como indicador de que existen buenas "razones para expulsar a las presunciones iure et de iure del mundo de las presunciones,
} 
Polít. crim. Vol. 10, No 19 (Julio 2015), Art. 11, pp. 318-361.

[http://www.politicacriminal.cl/Vol_10/n_19/Vol10N19A11.pdf]

Lo anterior es visto por los autores contemporáneos simplemente como una evidencia más de la estrechez de la doctrina tradicional. Y es que su error fundamental, como hemos visto, radica en restringir la comprensión de las reglas de presunción al mero establecimiento de vinculaciones racionales entre dos hechos, obviando, injustificadamente, el hecho de que existen normas de presunción que vinculan directamente ciertos hechos con alguna consecuencia jurídica $^{47}$.

En atención a defectos como el descrito, esos mismos autores han afirmado la necesidad de superar los márgenes de la doctrina tradicional, comenzando por reconocer el hecho de que existen reglas de presunción que no tienen finalidades meramente fácticas (probatorias), sino que también existe un grupo de aquéllas que posee derechamente finalidades sustantivas. En particular, éstas tendrían por objeto crear resultados institucionales. De ahí que, según este sector de la doctrina, esta segunda clase de presunciones legales puede comprenderse mejor acudiendo a la noción de reglas constitutivas ${ }^{48}$.

estipulando que el ámbito en que las presunciones operan es el de la verdad fáctica”. AGUILÓ-REGLA, Josep, "Nota sobre "presunciones" de Daniel Mendoca", Doxa no 22 (1999), pp. 657 - 658.

${ }^{47}$ En este mismo orden de ideas, Josep Aguiló-Regla ha sostenido que muchas de las confusiones de la doctrina tradicional tienen su origen en que ésta no ha sido capaz de comprender que sólo aquellas normas de presunción que tienen finalidades fácticas (establecer vinculaciones racionales entre dos hechos) podrían ser catalogadas de verdaderas reglas probatorias. Sobre la base de esta reflexión, el mencionado autor sostiene que: "...meter en el mismo "saco" a todas las "presunciones" lleva a confundir dos relaciones que me parecen claramente diferentes: la relación entre hecho probado y hecho presumido, por un lado y la relación entre hecho probado y hecho constituido (o resultado institucional). La primera relación tiene que ver con los hechos del caso, afecta a la verdad fáctica, su ámbito es, por decirlo de algún modo el mundo natural y, por tanto, se sitúa en el mundo de la prueba (...) [1]a segunda, por el contrario, tiene que ver con la calificación jurídica de los hechos al caso a los resultados institucionales y, por lo tanto, se sitúa fuera del ámbito de la prueba. El problema aquí no es determinar qué ha ocurrido (lo que constituiría un problema de prueba), sino cómo calificar lo ocurrido con el fin de atribuirle unas u otras consecuencias jurídicas". AGUILÓ-REGLA, "Nota sobre", cit. nota $\mathrm{n}^{\circ} 46$.

${ }^{48}$ En este sentido, por ejemplo, la autora italiana Giovanna Fabbrini ha sostenido que ciertas presunciones (las de Derecho o absolutas) "se asemejan a lo que en el ámbito de la teoría del Derecho, se conoce como reglas constitutivas, en la medida en que se establece una situación de hecho o un determinado estado de cosas que ha de verificarse para que tenga lugar un determinado resultado institucional". FABBRINI, Giovanna. "Note in tema di presunción legali", Rivista Trimestrale di Diritto e Procedura Civile, ${ }^{\circ}$ XLV-3 (1991). Citada por GAMA, "Concepciones", cit. nota $\mathrm{n}^{\circ}$ 42, p. 78. En el mismo orden de ideas Gama ha constatado que: "Some legal theorists have sustained correctly that presumptions rules can be interpretated also as qualifying dispositions with the form " $X$ is $G$ " and in the case of irrebuttable presumptions, they can be interpretated as purely constitutive rule - whose canonical form would be "if the state of affairs $X$ obtains, then the institutional result (or normative change) $R$ is produced" ("algunos teóricos del derecho han sostenido, correctamente, que las reglas de presunción pueden ser interpretadas como disposiciones cualificatorias con la forma "X es G" y, para el caso de las presunciones irrefutables, ellas pueden ser interpretadas como verdaderas reglas constitutivas - cuya forma canónica sería "si se comprueba el estado de cosas X, entonces se obtiene el resultado institucional (o cambio normativo) R" -trad. propia-. GAMA, Raymundo, "Some ideas about the nature of presumption rules.", en: AGUILÓ-REGLÁ, Josep (Ed.), Logic Argumentation and Interpretation. Stuttgart: Editorial Drunkhaus Nomos, 2007, p.160. Otro autor que puede ser incluido en esta breve enumeración es el español Rafael Hernández Marín. Hernández incluye a las presunciones dentro de la categoría de los enunciados cualificatorios, concepto que emplea para referirse a las reglas constitutivas (según este autor "los enunciados jurídicos que aquí llamamos "enunciados cualificatorios" son llamados por algunos autores como enunciados constitutivos". HERNÁNDEZ, Introducción, cit. nota n 40, p. 261). En este sentido, y más allá de la terminología empleada, este autor sostiene que, "a pesar de las apariencias, no hay ninguna diferencia real entre una presunción jurídica y un enunciado jurídico cualificatorio ordinario" (regla constitutiva). HERNÁNDEZ, Introducción, cit. nota n ${ }^{\circ}$ 40, p. 324. En el mismo orden de ideas, Josep 
SALAZAR, Andrés. "El delito de mantención de la venta de alimentos defectuosos al público: Una revisión del artículo 315 del Código Penal a partir de la teoría de las presunciones y de la dogmática de los delitos de omisión propia".

En definitiva, y resumiendo lo hasta aquí estudiado, podemos afirmar que no todas las presunciones legales pueden ser entendidas desde una óptica probatoria debido a que existen ciertos enunciados normativos que, a pesar de recurrir explícitamente al término "presunción", a nivel estructural, no conectan hechos con hechos (hechos conocidos o base con hechos desconocidos o presumidos), sino que, muy por el contrario su finalidad es asignar a un determinado hecho (una vez acreditado) una determinada consecuencia jurídico-institucional. Lo anterior ha llevado a muchos autores a sostener que este segundo tipo de presunciones puede ser entendido de mejor forma acudiendo al concepto de reglas constitutivas.

Si esto es así, entonces, debe aceptarse que este segundo tipo de presunciones permite la creación de hechos institucionales a través del establecimiento de relaciones de equivalencia, tal y como describe la formula lógica propuesta por John Searle para las reglas constitutivas ("X cuenta como $\mathrm{Y}$ en el contexto C").

Las consideraciones aquí anotadas serán de enorme utilidad para la correcta interpretación de la norma contenida en el inciso $3^{\circ}$ del Artículo $315 \mathrm{CP}$.

Sin embargo, previo a ello, quisiéramos comprobar la tesis que aquí se sostiene, confrontándola con algunas normas no penales de presunción, insertas en nuestro sistema jurídico, como una forma de encontrar algún tipo de soporte empírico para lo que se sostendrá más adelante.

\subsection{Algunos ejemplos de presunciones con efecto constitutivo en el derecho chileno.}

A nuestro juicio, la noción de reglas constitutivas permite comprender de mejor manera una gran cantidad de enunciados normativos que, formando parte del Derecho chileno, hacen uso de la palabra "presunción" para explicitar su contenido.

Esta hipótesis puede ser verificada acudiendo a los siguientes ejemplos:

\subsubsection{Renta presunta (Artículos 20, 34 y 34 bis de la Ley de Impuesto a la Renta).}

Para comenzar, analizaremos la institución de la renta presunta. Ésta, como su propio nombre lo indica, se construye a través de una "presunción" y pretende establecer un beneficio para algunas actividades comerciales o extractivas (venta de bienes raíces, actividades agrícolas y mineras) en el contexto de las normas que determinan las cargas impositivas que las empresas deben soportar en nuestro país, estableciendo un trato preferencial para aquéllas que cumplan con los requisitos dispuestos en la ley y opten por esta forma de tributar, extrayéndolas del régimen general de la primera categoría del

Aguiló-Regla ha señalado que a su juicio la clave para comprender aquellas presunciones que no encajan bajo la concepción tradicional "...radica en desvincularlas del ámbito de la verdad fáctica y resituarlas en el ámbito de la constitución de resultados institucionales y de la imputación de consecuencias jurídicas”. Por ello, el mencionado autor advierte que "[d]esarrollar esta idea requiere (...) echar mano de la noción de regla puramente constitutiva..."AGUILÓ-REGLA, "Nota sobre", cit. nota n 46, p. 660. 
Polít. crim. Vol. 10, № 19 (Julio 2015), Art. 11, pp. 318-361.

[http://www.politicacriminal.cl/Vol_10/n_19/Vol10N19A11.pdf]

impuesto a la renta, pudiendo pagar sus impuestos sobre la base de una renta determinada de manera distinta que el resto de las personas jurídicas ${ }^{49}$.

Pues bien, ¿qué tiene que ver esta presunción con una regla probatoria? La respuesta es simplemente nada. El contribuyente que cumple los requisitos establecidos por el legislador y opta por tributar bajo este régimen, en realidad no pretende que la acreditación de un determinado hecho base le ayude a determinar su renta imponible de acuerdo con las reglas generales (renta efectiva como hecho desconocido).

Como es obvio, la presunción de que se trata toma un dato externo a la verdadera actividad comercial desarrollada por el contribuyente durante un determinado período tributario (dato, que, de acuerdo a esta regla, por ejemplo, se refiere un determinado porcentaje del avalúo fiscal de los predios agrícolas que éste posee) y determina que ese dato, equivale o cuenta como renta para los efectos de esta ley.

En buenas cuentas, nos encontramos ante una regla de presunción que dispone una determinada consecuencia jurídica sobre la base de ciertos supuestos de hecho y que sólo se puede comprender adecuadamente entendiéndola como una regla constitutiva.

\subsubsection{Presunción de extraterritorialidad aduanera en zonas francas.}

Otro caso similar al anterior lo podemos apreciar a través del estudio de los artículos $2^{\circ}$ y 24 del D.F.L. No 341 de 1977, sobre zonas francas.

De acuerdo con lo dispuesto en el artículo $2^{\circ}$ del referido estatuto, una zona franca se define, institucionalmente, como el lugar donde rige la presunción de extraterritorialidad. Por su parte, el artículo 24 del D.F.L. No 341 define la presunción de extraterritorialidad señalando que ésta consiste en una ficción legal, a través de la cual, se entiende que (a pesar de ya haber ingresado a nuestro país) mientras la mercancía permanezca en una zona franca se considerará que ella se encuentra en el extranjero, y en consecuencia, no se encontrará afecta al pago de los derechos aduaneros ${ }^{50}$.

\footnotetext{
${ }^{49}$ Por motivos de extensión a continuación sólo se transcribe parte del artículo 20 de la LIR, en lo pertinente a la renta presunta en la venta de inmuebles:

"Artículo $20^{\circ}$.- Establécese un impuesto de $21 \%$ que podrá ser imputado a los impuestos global complementario y adicional de acuerdo con las normas de los artículos 56, $\mathrm{N}^{\circ} 3$ y 63 . Este impuesto se determinará, recaudará y pagará sobre:

1.- La renta de los bienes raíces en conformidad a las normas siguientes:

b) Los contribuyentes propietarios o usufructuarios de bienes raíces agrícolas, que no sean sociedades anónimas y que cumplan los requisitos que se indican más adelante, pagarán el impuesto de esta categoría sobre la base de la renta de dichos predios agrícolas, la que se presume de derecho es igual al 10\% del avalúo fiscal de los predios. Cuando la explotación se haga a cualquier otro título se presume de derecho que la renta es igual al $4 \%$ del avalúo fiscal de dichos predios. Para los fines de estas presunciones se considerará como ejercicio agrícola el período anual que termina el 31 de diciembre

Para acogerse al sistema de renta presunta las comunidades, cooperativas, sociedades de personas $u$ otras personas jurídicas, deberán estar formadas exclusivamente por personas naturales....".

50 “Artículo $2^{\circ}$.- Para los efectos de este decreto ley, se entenderá por:

a) Zona Franca: El área o porción unitaria de territorio perfectamente deslindada y próxima a un puerto o aeropuerto amparada por presunción de extraterritorialidad aduanera...".
} 
SALAZAR, Andrés. "El delito de mantención de la venta de alimentos defectuosos al público: Una revisión del artículo 315 del Código Penal a partir de la teoría de las presunciones y de la dogmática de los delitos de omisión propia”.

Evidentemente, bajo los propios términos de la ley, no puede sostenerse de forma plausible que la presente presunción establezca una relación inferencial de carácter probatorio entre un hecho conocido y otro desconocido, de acuerdo a lo postulado por la doctrina estándar. $\mathrm{Y}$ esto es así porque, en el caso en comento, nunca se podría acreditar la veracidad del hecho desconocido ("las mercancías se hallan en el extranjero") porque los bienes a los cuales ésta se refiere se encuentran, necesariamente, en territorio chileno.

Por lo tanto, esta norma, nuevamente, permite leerse de mejor manera como una regla constitutiva, que dispone que si una mercancía se encuentra en una zona franca, para efectos aduaneros, cuenta como (o equivale) a que ésta se encuentre en el exterior ${ }^{51}$.

\subsection{El efecto constitutivo tipificador de la expresión "presunción" utilizada en la regla del inciso $3^{\circ}$ del artículo 315 del Código Penal.}

Durante las páginas anteriores, hemos visto que la doctrina tradicional de las presunciones, a pesar de encontrarse fuertemente arraigada entre nosotros, comete el error de entender que toda norma que acude a dicha expresión en el Derecho posee un contenido probatorio estructurado de acuerdo a una particular forma de inferencia (judicial). En contra de esto, y coincidiendo con quienes postulan una concepción plural de las presunciones, hemos verificado que, en algunas ocasiones, el término "presunción" es utilizado en el Derecho para hacer referencia a reglas constitutivas cuyo propósito es el de instaurar determinados resultados institucionales a través del establecimiento de relaciones de equivalencia en un específico contexto jurídico. Los ejemplos invocados en el acápite anterior constituyen una clara demostración de lo que aquí se afirma.

Habiendo llegado, entonces, a estas conclusiones, es el momento de analizar el enunciado normativo contenido en inciso $3^{\circ}$ del Art. 315 del CP, pero dotados ahora de nuevas (y mejores) herramientas.

Atendido lo estudiado durante las páginas precedentes, entendemos que la citada regla se trata de una presunción con efectos constitutivos, cuya finalidad es la de tipificar la conducta de "tener a la venta en un lugar público alimentos infectados, envenenados o adulterados" por la vía de entender que la descrita se trata de una conducta equivalente a la de vender o distribuir los mismos productos en términos de su (des)valoración jurídico penal.

Artículo 24.- Mientras las mercancías permanezcan en las Zonas Francas, se considerarán como si estuvieran en el extranjero y, en consecuencia, no estarán afectas al pago de los derechos, impuestos, tasa y demás gravámenes que se perciban por intermedio de las Aduanas, incluso la Tasa de Despacho establecida por la ley 16.464 y sus modificaciones...".

${ }^{51}$ Otras normas interesantes son la presunción que recae sobre las condiciones impuestas por el causante en una asignación testamentaria contenida en el artículo 1072 del Código Civil o la presunción de desacuerdo en la designación del perito inserta en el artículo 415 del Código de Procedimiento Civil. Ninguna de las dos normas tiene por objeto acreditar un hecho que se desconoce o invertir alguna carga probatoria. La única forma en que su lectura cobra sentido es entender dichas disposiciones como reglas constitutivas, las cuales otorgan efectos jurídicos al acaecimiento de ciertos hechos. 
Polít. crim. Vol. 10, № 19 (Julio 2015), Art. 11, pp. 318-361.

[http://www.politicacriminal.cl/Vol_10/n_19/Vol10N19A11.pdf]

La anterior conclusión es coherente, a nivel formal, con la estructura lógica que adoptan las reglas constitutivas y que puede graficarse de la siguiente forma:

\begin{tabular}{|l|l|l|}
\hline Texto del inciso $3^{\circ}$ del Artículo 315 & $\begin{array}{l}\text { Estructura formal de las reglas } \\
\text { constitutivas }\end{array}$ & \\
\hline $\begin{array}{l}\text { "se presumirá que...se configura por } \\
\text { el hecho tener a la venta en un lugar } \\
\text { público los artículos alimenticios } \\
\text { (envenenados, infectados o } \\
\text { adulterados)" }\end{array}$ & & \\
\hline $\begin{array}{l}\text { la situación de vender o distribuir } \\
\text { establecida en los incisos } \\
\text { precedentes } \quad \text { Y }\end{array}$ & \\
\hline "Para los efectos de este artículo..." & “...en el contexto C" \\
\hline
\end{tabular}

En otras palabras, la regla nos dice que la situación de tener a la venta en un lugar público los alimentos nocivos equivale a la situación de venderlos o distribuirlos, para efectos de este artículo. Y precisamente, el efecto que poseen los incisos primero y segundo del artículo 315 es el de tipificar la conducta de vender o distribuir alimentos nocivos. Luego, de lo anterior se concluye que el legislador ha querido hacer equivalentes, esto es, igualmente sancionables, las conductas de "vender o distribuir los alimentos nocivos o la de mantenerlos a la venta en un lugar público".

Pero, la posición aquí sostenida no es original de este autor. Ya el profesor Alfredo Etcheberry había llegado a esta conclusión en un pasaje, al parecer inadvertido, de su tratado de Derecho Penal, en donde señaló, respecto de este inciso, que:

"La ley establece ciertas presunciones para facilitar la persecución de estos delitos. En primer término, presume (más exacto sería decir que tipifica) la situación de "vender o distribuir" por el hecho de "tener a la venta en un lugar público" los artículos alimenticios..."

Por lo tanto, lo dicho hasta acá complementa la afirmación ya hecha por Etcheberry, al enfocarse las páginas anteriores en la justificación de las premisas que sirven de fundamento a la conclusión a la que arribó el mencionado autor y que coinciden con las propias.

Más allá de la mencionada cita y de los argumentos ya desarrollados (que a mi juicio permiten fundamentar debidamente la referida conclusión), es probable que al lector le siga

\footnotetext{
${ }^{52}$ ETCHEBERRY, Derecho Penal, cit. nota n ${ }^{\circ}$ 8, p. 290. Lo destacado es nuestro. Cabe hacer presente que la invocación a Etcheberry, en este caso particular, va más allá de la alusión a un mero argumento de autoridad. Y esto es así debido a que el profesor Etcheberry tuvo un destacado papel en la creación y tramitación parlamentaria del Proyecto de Ley que culminó con la dictación de la Ley $\mathrm{N}^{\mathrm{o}}$ 17.155.
} 
SALAZAR, Andrés. "El delito de mantención de la venta de alimentos defectuosos al público: Una revisión del artículo 315 del Código Penal a partir de la teoría de las presunciones y de la dogmática de los delitos de omisión propia”.

causando extrañeza la posibilidad aquí planteada, de que a partir de una norma que utiliza la expresión "presunción” se pueda llegar a configurar un tipo penal.

Tal preocupación, que podría parecer justificada desde un punto de vista apriorístico desaparece si se analiza íntegramente el ordenamiento jurídico-penal chileno. Y es que existen en nuestro sistema punitivo otras normas que, a pesar de utilizar el término "presunción", han sido entendidos por la doctrina y jurisprudencia como configuradoras de reglas de sanción (tipos penales), tal y como ocurre en el caso del inciso $3^{\circ}$ del artículo 315 del CP.

Sobre esto versarán las próximas líneas.

\subsection{Otras presunciones con efecto constitutivo tipificador en el Derecho Penal chileno de acuerdo con la doctrina.}

Tal y como anticipamos, la identificada no es la única presunción con efecto tipificador que conocemos en el derecho chileno.

En efecto, en nuestro ordenamiento penal, existen al menos dos normas presunción a las que tanto la doctrina como la jurisprudencia mayoritarias le han asignado un efecto tipificador. Nos referimos a las presunciones de contrabando contenidas en la Ordenanza Aduanera y a los delitos contenidos en la antigua Ley de Quiebras.

\subsubsection{Presunciones de contrabando impropio.}

Como sabemos el artículo 181 de la Ordenanza de Aduanas ${ }^{53}$, declara que se "presumen responsables" del delito de contrabando impropio quienes realicen alguna de las siete

\footnotetext{
${ }^{53}$ Artículo 181.- Se presumen responsables del delito de fraude las personas que cometan o intervengan en los siguientes actos:

a) Importar o exportar, o tratar de importar o exportar mercancías después que el dueño, consignatario o agente haya extendido presentaciones o declaraciones falsas referentes a dichas mercancías o relacionadas con su importación o exportación;

b) Intentar la importación o exportación, o importar o exportar mercancías después de haber redactado o entregado facturas, cartas u otros documentos falsos concernientes a dichas mercancías y que sirvan para conseguir la entrega de ellas o para obtener con ellos otras especies por medio de manejos, procedimientos, omisiones y actos que despojan al Fisco de sus derechos sobre las mercancías;

c) Transportar mercancías o guardarlas en envases o dentro de objetos que las oculten para no declararlas a la Aduana o que engañen o induzcan a error cuando se las exhiban;

d) Obtener engañosamente la liberación o la reducción de derechos para mercancías que no cumplen con las condiciones prescritas en la ley para concederlas;

e) Emplear con distinto fin del declarado, y sin autorización o sin pagar los derechos correspondientes, mercancías afectas a derechos menores con la condición de un uso determinado de ellas;

f) Vender, disponer o ceder a cualquier título y consumir o utilizar en forma industrial o comercial mercancías sujetas al régimen suspensivo de derechos de admisión temporal o almacenaje particular sin haber cubierto previamente los respectivos derechos, impuestos y otros gravámenes que las afecten o sin haber retornado a la potestad aduanera y cumplido las obligaciones existentes a su respecto, una vez expirado el plazo de la franquicia, y

g) Exportar, enajenar, arrendar o destinar a una finalidad no productiva los bienes respecto de los cuales se hubiere obtenido el beneficio de pago diferido de tributos aduaneros, sin que se hubiere pagado el total de la
} 
Polít. crim. Vol. 10, № 19 (Julio 2015), Art. 11, pp. 318-361.

[http://www.politicacriminal.cl/Vol_10/n_19/Vol10N19A11.pdf]

hipótesis allí enumeradas. Sin embargo, más allá del fraseo empleado por el legislador nuestra doctrina ha destacado que la presente norma no contiene "verdaderas presunciones".

En este orden de ideas, se ha sostenido que las cuatro primeras conductas incluidas en esta norma simplemente constituyen especificaciones de lo que ya se encuentra proscrito en el inciso $2^{\circ}$ del artículo 168 de la Ordenanza de Aduanas, llegando incluso a calificarse a estas hipótesis como meras reiteraciones o una simple tautología ${ }^{54}$. Por su parte, las tres hipótesis restantes se tratarían simplemente de "tipos autónomos, pero asimilados al contrabando en cuanto a su penalidad y otros aspectos de orden sustantivo 55 ".

En otras, palabras, la doctrina nacional, a pesar de no apoyarse en una concepción plural de las normas de presunción (y de ahí que entiendan que en el Art. 181 está compuesto por "falsas presunciones"), ya ha constatado a propósito de la regla en estudio, que es perfectamente posible que una norma jurídica que acuda en su texto a la expresión "presunción" pueda ser utilizada para la tipificación de ciertas conductas ${ }^{56}$.

deuda, o sin haber obtenido autorización del Servicio de Aduanas en el caso de la enajenación o del arrendamiento.

${ }^{54}$ Así por ejemplo, Rodríguez y Ossandón han constatado con razón que las referidas hipótesis "no constituyen presunciones", en razón de que "todas ellas, en efecto, quedan comprendidas dentro del espectro de conductas que contempla el delito de contrabando impropio, de manera que presumir su pertenencia de este género implica, ni más ni menos, que incurrir en una tautología". RODRÍGUEZ, Luís; OSSANDÓN, María Magdalena, Delitos Aduaneros, Santiago: Editorial Jurídica de Chile, 2011, pp. 110 y 111.

${ }^{55}$ RODRÍGUEZ/OSSANDÓN, Delitos Aduaneros, cit. nota ${ }^{\circ} 54$, p. 111. A continuación profundizan dicha afirmación agregando que "[p]ese a la declaración que efectúa el artículo 181OA, las situaciones descritas en las letras e), f) y g) de este artículo no corresponden a presunciones. En efecto, según el artículo 44 CC la presunción consiste en deducir un hecho desconocido a partir de un hecho conocido, y en las situaciones que menciona el primero de los artículos nombrados, no sólo no existe un hecho desconocido, sino que además consta que el hecho que se pretende presumir jamás existió (...) En estas circunstancias, no cabe sino concluir que la Ordenanza de Aduanas, además de los tipos de contrabando propio e impropio, contempla tres figuras autónomas en cuanto a la materia de la prohibición, pero asimiladas a esos dos tipos en cuanto al régimen penal".

El mismo profesor Rodríguez ya se había manifestado cercano al punto de vista aquí defendido al analizar la constitucionalidad de las presunciones de contrabando contenidas en el antiguo Art. 187 de la OA, de acuerdo a la redacción que dicha norma poseía con anterioridad a la reforma que sufrió dicho cuerpo normativo el año 2001 con la entrada en vigencia de la Ley 19.738.

Sobre esto el mencionado autor esgrimió que existían “...poderosas razones que impiden atribuir a esas hipótesis el carácter que parece desprenderse de la letra de aquel precepto [presunción] (...) partiendo de la base que toda norma de presunción es básicamente de deducción de un hecho desconocido que la norma suponga existente, y como este requisito por cierto no se da en las hipótesis del artículo 187 Ord. Ads., debe concluirse que éstas no constituyen verdaderas presunciones, sino que tienen el alcance de asignar directamente el carácter de delito a las conductas que ellas contemplan". RODRÍGUEZ, Luís, "Sobre la constitucionalidad del tipo de fraude aduanero", Revista de Derecho de la Universidad Católica de Valparaíso, $\mathrm{n}^{\circ} 15$ (1993), pp. 340 y 341. Lo destacado es nuestro.

${ }^{56}$ En un sentido similar al esbozado por Rodríguez y Ossandón, pero refiriéndose ahora a las presunciones de contrabando propio ( $\mathrm{y}$ a pesar de que al igual que los citados autores, entiende a las reglas de presunción desde la visión estándar de ellas) Horvitz señala que “...una interpretación sistemática obliga a considerar las hipótesis contenidas en el artículo 179 OA, no ya entendidas como presunciones legales de delito -las que contrarían la presunción de inocencia, la libra valoración de la prueba y el principio de que la carga de la prueba, en materia penal corresponde al Estado- sino como modalidades de contrabando específicamente 
SALAZAR, Andrés. "El delito de mantención de la venta de alimentos defectuosos al público: Una revisión del artículo 315 del Código Penal a partir de la teoría de las presunciones y de la dogmática de los delitos de omisión propia”.

3.5.2. Presunciones de quiebra punible.

Otro tanto, puede decirse de las antiguas presunciones de quiebra que permanecían como derecho vigente en nuestro país hasta el reciente reemplazo de la Ley $\mathrm{N}^{\mathrm{o}} 18.175$ por la Ley $\mathrm{N}^{\mathrm{o}} 20.720$ de 09 enero de 2014.

Al respecto cabe hacer presente que si bien la doctrina nacional siempre manifestó sus recelos frente a la forma en que el legislador construyó las normas penales contenidas en los artículos $219^{57}$ y $220^{58}$ de la Ley de Quiebras, con el tiempo se llegó a un sólido

reguladas por la ley". HORVITZ, MARÍA INÉS, "Problemas de aplicación de la Ley Penal en el tiempo en los delitos aduaneros", Revista de Estudios de la Justicia $\mathrm{N}^{\circ} 3$ (2003), p. 129.

${ }^{57}$ ARTICULO 219: La quiebra se presume culpable en los siguientes casos:

1.- Si el deudor ha pagado a un acreedor en perjuicio de los demás, después de la cesación de pagos;

2.- Si los gastos domésticos o personales del fallido hubieren sido excesivos, habida consideración a su capital, a su rango social y al número de personas de su familia;

3.- Si el fallido hubiere perdido fuertes sumas en cualquier especie de juego, en apuestas cuantiosas o en operaciones aventuradas de bolsa;

4.- Si el deudor no hubiere solicitado su quiebra, en el caso del artículo 41, o si la manifestación que hiciere no reuniese las condiciones que prescribe el artículo 42;

5.- Si el deudor fuere declarado en quiebra, por segunda vez, sin haber cumplido las obligaciones que hubiere contraído en un convenio precedente;

6.- Si se ausentare o no compareciere al tiempo de la declaración de quiebra o durante el curso del juicio, o si se negare a dar al síndico explicaciones sobre sus negocios;

7.- Si hubiere prestado fianzas o contraído por cuenta ajena obligaciones desproporcionadas a la situación que tenía cuando las contrajo, sin garantías suficientes;

8.- Si hubiere hecho donaciones desproporcionadas a su situación de fortuna, considerada en el momento de hacerlas;

9.- Si no tuviere libros o inventarios o si teniéndolos, no hubieren sido llevados los libros con la regularidad exigida de tal suerte que no manifiesten la verdadera situación de su activo y pasivo. Respecto de quienes no estén obligados a llevar libros de contabilidad, se aplicarán las normas sobre tributación simplificada establecidas por el Servicio de Impuestos Internos;

10.- Si no se conservare las cartas que se le hubieren dirigido con relación a sus negocios;

11.- Si hubiere omitido la inscripción de los documentos que ordena la ley, y

12.- $\mathrm{Si}$ agravase el mal estado de sus negocios durante el período a que se refiere el inciso primero del artículo 177 bis.

${ }^{58}$ ARTICULO $220^{\circ}$ Se presume fraudulenta la quiebra del deudor:

1.- Si hubiere ocultado bienes;

2.- Si hubiere reconocido deudas supuestas;

3.- Si hubiere supuesto enajenaciones, con perjuicio de sus acreedores;

4.- Si hubiere comprometido en sus propios negocios los bienes que hubiere recibido en depósito, comisión o administración, o en el desempeño de un cargo de confianza;

5.- $\mathrm{Si}$, posteriormente a la declaración de quiebra, hubiere percibido y aplicado a sus propios usos, bienes de la masa;

6.- $\mathrm{Si}$, después de la fecha asignada a la cesación de pagos, hubiere pagado a un acreedor, en perjuicio de los demás, anticipándole el vencimiento de una deuda;

7.- Si ocultare o inutilizare sus libros, documentos y demás antecedentes;

8.- $\mathrm{Si}$, con intención de retardar la quiebra, el deudor hubiere comprado mercaderías para venderlas por menor precio que el corriente, contraído préstamos a un interés superior al corriente de plaza, puesto en circulación valores de crédito o empleado otros arbitrios ruinosos para hacerse de fondos;

9.- $\mathrm{Si}$, inmediatamente después de haber comprado mercaderías al fiado, las vendiere con pérdidas;

10.- $\mathrm{Si}$, antes o después de la declaración de quiebra, hubiere comprado para sí por interposición de un tercero y a nombre de éste, bienes de cualquier clase; 
Polít. crim. Vol. 10, № 19 (Julio 2015), Art. 11, pp. 318-361.

[http://www.politicacriminal.cl/Vol_10/n_19/Vol10N19A11.pdf]

consenso en el sentido de que dichas reglas, si bien utilizaban la voz "presunción" en su texto, lo que hacían realmente eran tipificar las conductas allí descritas.

En este sentido, por ejemplo, se manifestó Garrido quien afirmó que las citadas normas "...no constituyen jurídicamente presunciones de naturaleza probatoria, sino simples descripciones de los comportamientos prohibidos"59. Por su parte, Etcheberry señaló al respecto que "...las disposiciones [de la ley de quiebras] que establecen "presunciones" en realidad no tienen tal papel, sino una verdadera función tipificadora. Esas normas solamente tipifican conductas..."60.

De esta forma, queda claro que los autores nacionales, más allá de la terminología empleada, coinciden con lo que aquí se ha sostenido en cuanto a que la expresión presunción, en ciertas ocasiones, (como sucede en el caso de los delitos de contrabando o en los contenidos en la antigua ley de quiebras) puede ser utilizada por el legislador con una finalidad tipificadora.

\subsection{Conclusión preliminar.}

Todo lo consignado anteriormente demuestra, que al menos a nivel pragmático, en el lenguaje jurídico, existe un uso del término presunción que tiene por finalidad tipificar conductas elevándolas a la calidad de delito.

Este uso del lenguaje técnico, si bien ha pasado desapercibido para buena parte de nuestros juristas (en buena medida por la fuerza que adquirió la concepción estándar de las presunciones que, como vimos, pretendió encasillar el uso del término de que se trata sólo en referencia a una regla de inferencia de contenido probatorio), se encuentra plenamente vigente en la práctica, dado que nuestro legislador ha establecido delitos acudiendo al término "presunción" y nuestros tribunales han utilizado esas reglas de presunción para sancionar penalmente las conductas incluidas en ellas.

Pero, además del aludido argumento pragmático, hemos visto que a través de la concepción plural de las presunciones, citada más arriba, ciertas reglas de presunción pueden ser entendidas como reglas constitutivas que crean realidades institucionales a través del establecimiento de relaciones de equivalencia normativa. $\mathrm{Y}$ es sobre la base de esta

11.- Si no resultare de sus libros la existencia o salida del activo de su último inventario, o del dinero y valores de cualquier otra especie que hubieren entrado en su poder posteriormente a la facción de aquél; 12.- $\mathrm{Si}$, en estado de manifiesta insolvencia, hubiere hecho donaciones cuantiosas;

13.- $\mathrm{Si}$ hubiere celebrado convenios privados con algunos acreedores en perjuicio de la masa;

14.- Si se ausentare o fugare, llevándose una parte de sus haberes;

15.- Si el deudor, dentro del ejercicio en el cual cese en el pago de sus obligaciones o en el inmediatamente anterior, hubiere omitido, falseado o desvirtuado información de aquella que ha debido proporcionar de conformidad a la ley, acerca de su real situación legal, económica o financiera, y

16.- En general, siempre que hubiere ejecutado dolosamente una operación cualquiera que disminuya su activo o aumente su pasivo.

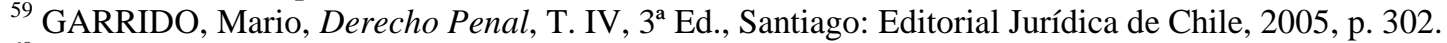

${ }^{60}$ ETCHEBERRY, Derecho Penal, T. III., cit. nota ${ }^{\circ}$ 8, pp. 382 y 383. Lo puesto entre corchetes es nuestro. También en este sentido, PUGA, Juan, Derecho Concursal. Delitos de la quiebra, $2^{a}$ Ed., Santiago: Editorial Jurídica de Chile, 2002, p. 36. 
SALAZAR, Andrés. "El delito de mantención de la venta de alimentos defectuosos al público: Una revisión del artículo 315 del Código Penal a partir de la teoría de las presunciones y de la dogmática de los delitos de omisión propia”.

concepción que pueden comprenderse de mejor manera las reglas de presunción que (entre otras consecuencias institucionales) determinan el establecimiento de delitos.

La ausencia de este instrumental conceptual, ha llevado a quienes se enfrentan con reglas de presunciones de efectos tipificadores, a denunciar la existencia de "falsas presunciones" (y sin embargo, reconocer, que están ante la presencia de un tipo penal).

Precisamente, este es el caso de la regla del inciso $3^{\circ}$ del artículo 315 del Código Penal. Se trata de una norma que si bien emplea la palabra presunción, lo hace aludiendo a su potencial configurador de realidades institucionales, equiparando la conducta de mantener a la venta en un lugar público un alimento nocivo a las de vender o distribuir el mismo producto, en cuanto a su proscripción por parte del sistema jurídico. Tal decisión de equiparar institucionalmente las conductas de "vender" o "distribuir" el producto nocivo con la de "mantenerlo a la venta", ha sido adoptada por el legislador considerado que todas ellas afectan de la misma forma al bien jurídico colectivo protegido: la salud pública.

\section{Análisis del delito contenido en el inc. $3^{\circ}$ del Artículo 315 CP. Acerca del delito de omisión propia (pura) de mantener alimentos a la venta del público, en general, y de la conducta (activa) ordenada por la norma jurídico-penal.}

Determinada ya la calidad de tipo penal que se puede atribuir al enunciado normativo contenido en el inciso $3^{\circ}$ del artículo 315 del CP, corresponde ahora analizarlo y desentrañar el real sentido y alcance de la norma de conducta en él contenida.

De acuerdo con lo sostenido en las páginas anteriores, a estas alturas para el lector será evidente que la conducta que se prohíbe en la norma de la referencia es la de mantener a la venta el producto infectado, contaminado, adulterado o disminuido en sus propiedades nutricionales, en un lugar de libre acceso al público.

En primer lugar, desde el prisma de la tipicidad objetiva, debemos señalar que estamos de acuerdo con Etcheberry cuando expresa que "tener a la venta" debe ser entendido como ofrecer los productos "al público general, de ordinario mediante su exhibición”. También, lleva razón este autor cuando señala que por "lugar público" debe comprenderse un espacio "abierto indiscriminadamente al público, que tiene libre acceso a él". A este respecto, cabría agregar desde una perspectiva contemporánea, sería posible incluir dentro de la noción "lugar público" a las páginas web donde los consumidores pueden acceder a comprar productos alimenticios, sin restricción alguna ${ }^{61}$.

Un aspecto muy importante a desentrañar es si el delito al cual nos estamos refiriendo es uno de acción o de omisión. En otras palabras, necesitamos determinar cuál es el contenido deóntico del tipo penal en análisis.

${ }^{61}$ ETCHEBERRY, Derecho Penal, T. III., cit. nota n ${ }^{\circ}$ 8, p. 290. 
Polít. crim. Vol. 10, № 19 (Julio 2015), Art. 11, pp. 318-361.

[http://www.politicacriminal.cl/Vol_10/n_19/Vol10N19A11.pdf]

En primer lugar, cabe destacar que el presente, tal y como ha sido descrito en las páginas anteriores, parece tratarse de un delito de posesión ${ }^{62}$. Ello debido a que, como ya sabemos, lo que se sanciona en esta norma es el tener a la venta en un lugar público un producto nocivo para la salud de la población. En esta medida, la tenencia del producto defectuoso constituye un requisito sine qua non para la procedencia del castigo penal.

Si esto es así, sin embargo, nos enfrentamos a un nuevo problema, ya que catalogar una norma que prohíbe penalmente la posesión de determinados objetos, como un delito de acción o de omisión, ha sido una cuestión controvertida para la dogmática penal.

Así por ejemplo, algunos autores han defendido la idea de que la tenencia de objetos prohibidos se plasmaría en delitos de comisión, dado que "tener" o "mantener" una cosa constituiría una actividad ${ }^{63}$; otros han sostenido que tras un delito de posesión existe un mandato, mandato que generaría el deber, para quién tiene la cosa, de deshacerse de ella, por lo cual, los ilícitos de posesión deberían caracterizarse como delitos de omisivos que se consumarían con la no realización de la acción debida (p. ej., deshacerse de la cosa) ${ }^{64}$; finalmente, existen quienes piensan que estos delitos no pueden ser catalogados ni como delitos de acción, ni como delitos omisión, ya que la "tenencia", no describiría ninguna conducta $^{65}$.

Los problemas exhibidos por la doctrina al momento de dilucidar este punto tienen su fuente en la estructura normativa de los delitos de posesión, ya que, como bien lo ha puesto de relieve Mañalich, estas normas poseen la característica de ser "silogísticamente opacas". En términos didácticos, con el empleo de dicha noción se quiere poner de manifiesto que el especifico contenido proposicional de una norma que proscribe la posesión de un determinado objeto dependerá, en concreto, de la -contingente- situación (o relación) que mantenga el agente con la cosa de que se trata, en un momento determinado ${ }^{66}$. En estos

\footnotetext{
${ }^{62}$ Fundamental, COX, Juan Pablo, Delitos de Posesión. Bases para una dogmática, Buenos Aires: Editorial B de F, 2012.

${ }^{63}$ COX, Delitos de posesión, cit. nota n ${ }^{\circ} 62$, pp. 133; 180-182.

${ }^{64}$ Así, PASTOR, NURIA, Los delitos de posesión y los delitos de estatus: una aproximación político criminal y dogmática. Barcelona: Editorial Atelier, 2005, p. 39 y ss.

${ }^{65}$ En este sentido, STRUENSSE, Eberhard, "Los delitos de tenencia", en: JAKOBS, Günter y STRUENSSE, Eberhard, Problemas capitales del derecho penal moderno, Buenos Aires: Editorial Hamurabi, 1998, p. 107. Asimismo, SCHROEDER, Friedrich-Christian, "La posesión como hecho punible", Revista de Derecho Penal

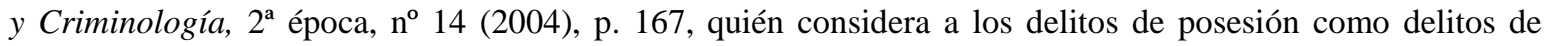
estado. Desde esta perspectiva, los delitos de posesión infringirían el "principio del hecho" y su legitimidad estaría constitucionalmente cuestionada.

${ }^{66}$ Así por ejemplo: “...si la posesión de material pornográfico en cuya elaboración hayan sido utilizados menores de edad se encuentra sometida a prohibición, entonces, lo que tenga que hacer o dejar de hacer cualquiera de los posibles destinatarios de esta norma, en pos de adecuar su comportamiento a ésta, dependerá de cuál sea su posición situacional relativa al material cuya detentación es objeto de prohibición. Así, quién (aún) no está en posesión de material semejante tiene que abstenerse de llegar a estarlo, esto es: omitir cualquier acción cuyo resultado consista en una adquisición de tenencia del material en cuestión; en cambio, quien se encuentra (ya) en posesión de semejante material, tiene que efectuar una reversión de ese estado, esto es, ejecutar una acción cuyo resultado consista en una extinción de la tenencia del material en cuestión”. En otros términos, "[1]a opacidad silogística de semejante norma prohibitiva se muestra entonces, en que ella puede fundamentar deberes cuyo cumplimiento circunstancial volverá "prácticamente necesaria" la ejecución
} 
SALAZAR, Andrés. "El delito de mantención de la venta de alimentos defectuosos al público: Una revisión del artículo 315 del Código Penal a partir de la teoría de las presunciones y de la dogmática de los delitos de omisión propia”.

términos, si una persona tiene en su poder un objeto prohibido su obligación será la de deshacerse de aquél; en cambio, si el agente aún no ha adquirido la posesión de la cosa, su obligación será la de abstenerse de poseerla.

No obstante, creemos que la aludida dificultad ha sido sorteada con éxito por Cox, quien ha sostenido, convincentemente, que quien posee actúa, y por lo tanto, podemos decir que, al menos, en un nivel abstracto (o genérico), los delitos de posesión son delitos comisivos ${ }^{67}$ donde lo prohibido es un determinado estado de cosas (la posesión).

Pero la aceptación que aquí se realiza de los resultados del estudio emprendido por Cox, debe ser matizada.

Si bien entendemos que en abstracto, dicha conclusión sería aplicable para la mayor parte de los delitos de posesión contemplados en nuestro ordenamiento jurídico-penal (especialmente, respecto de aquellos en donde lo prohibido es derechamente la tenencia, mantención o control de un determinado objeto, como sucede con los delitos que sancionan la posesión de drogas o de armas), al mismo tiempo, estimamos que el baremo fundamental desde donde debe determinarse concretamente el contenido deóntico de una específica norma que prohíbe la posesión, se encuentra en los respectivos tipos delictivos de la parte especial del Código Penal ${ }^{68}$. Y esto es así, debido a que los tipos penales, en cuanto normas de sanción, especifican el carácter, contenido y las condiciones de aplicación de las respectivas prescripciones o prohibiciones a través de su concreta formulación linguiística. En este orden de ideas, volviendo al delito del inc. $3^{\circ}$ del Art. 315, es posible apreciar que éste no se trata, en puridad, de un delito de "mera tenencia". De hecho, si se presta la debida atención a todas las normas penales contenidas en el mismo artículo $315 \mathrm{CP}$ podremos observar que, en sí misma, la (sola) posesión de alimentos defectuosos no se encuentra prohibida en ninguna de sus hipótesis. En otras palabras, de acuerdo con el texto del Art. $315 \mathrm{CP}$, una persona puede mantener bajo su esfera de custodia alimentos nocivos para la salud de la población y, por ese solo hecho, no recibirá sanción penal alguna ${ }^{69}$.

Por su parte, en lo que se refiere específicamente al inciso $3^{\circ}$ del Art. $315 \mathrm{CP}$, debemos destacar que si bien resulta ser una condición necesaria para la aplicación de este delito la tenencia del alimento defectuoso, también es cierto que dicha tenencia no es condición suficiente para imposición del castigo. Y ello es así porque la tenencia de los alimentos deteriorados debe ser acompañada de otros dos aspectos situacionales: (a) que los alimentos poseídos se encuentren en un lugar abierto al público y (b) que esa tenencia se encuentre destinada a la venta dichos productos.

o la omisión de alguna acción, no obstante tratarse de una norma que consiste en nada más que la prohibición de estados de cierto tipo". MAÑALICH, Norma, Causalidad y Acción, cit. nota no 6, p. 29.

${ }^{67}$ Coincide también MAÑ̃LICH, Norma, Causalidad y Acción, cit. nota no 6, p. 31 .

${ }^{68}$ El mismo Cox parecería encontrarse abierto a tal posibilidad, impresión que se deriva de la constatación que realiza tal autor de la posibilidad de que exista un mandato secundario, respecto de la prohibición principal de poseer la cosa prohibida, en esta clase de ilícitos. COX, Delitos de Posesión, cit. nota $\mathrm{n}^{\circ}$ 62, pp. $180 ; 263$.

${ }^{69} \mathrm{Y}$ esto incluye al productor de alimentos defectuosos, quien no es sancionado por mantener dolosamente bajo su control artículos alimenticios riesgosos para la salud, sino por fabricarlos o producirlos. 
Polít. crim. Vol. 10, № 19 (Julio 2015), Art. 11, pp. 318-361.

[http://www.politicacriminal.cl/Vol_10/n_19/Vol10N19A11.pdf]

La consideración de estas dos circunstancias complementarias a la mera tenencia de los alimentos defectuosos y cuya concurrencia es exigida por el legislador para la aplicación del castigo penal, a nuestro juicio, alteran las consecuencias interpretativas a las que arriba Cox para la generalidad de los delitos de posesión. Y ello es así, porque lo prohibido es la tenencia dirigida a la venta, esto es, una instancia especifica de la actividad genérica de vender $^{70}$. Por lo tanto, el legislador parte de la base de que el sujeto a quién dirige el requerimiento, ya se encuentra en posesión del alimento.

De la constatación de esta circunstancia, se infiere que lo que el legislador ha buscado con la incorporación del inciso $3^{\circ}$ es evitar, a toda costa, que un alimento nocivo o deteriorado llegue a manos de los consumidores. De esto se sigue, a su vez, que lo demandado por el ordenamiento jurídico, en un contexto situacional como el descrito por la norma, es que quién mantenga alimentos defectuosos a la venta, en lugares abiertos al público, deje de hacerlo; esto es, la norma requiere de su destinatario que destruya dicho estado de cosas.

En otras palabras, el delito contemplado en el inciso $3^{\circ}$ del Art. 315 del CP es un delito de omisión, ya que contiene un mandato para el agente al que se dirige, consistente en destruir el estado de cosas "mantención a la venta de alimentos nocivos", castigando, consecuentemente, la inactividad de éste y la permanencia de dicha situación ${ }^{71}$.

En esta medida, recurriendo a la terminología tradicional, el ilícito en estudio se trataría de un delito de omisión propia (al encontrarse expresamente tipificado en la ley) y el contenido del deber incluido en dicha norma es el de la realización de una acción (cualquiera) lo suficientemente poderosa como para destruir el proceso cuya perpetuación se pretende evitar ${ }^{72}$, esto es, la mantención de la venta de un producto alimenticio infectado, envenenado, adulterado o deteriorado. Así por ejemplo, el agente que se encuentra a cargo de la venta directa al público del alimento defectuoso (sea éste el mismo sujeto que lo elaboró - a través de locales de su propia compañía- o un comerciante distinto del productor) y que toma conocimiento de la peligrosidad de éste, tiene el deber de detener el proceso de venta del producto; se encuentra obligado a dejar de ofrecerlo a potenciales consumidores $^{73} \cdot{ }^{74}$.

\footnotetext{
${ }^{70}$ En este sentido, el verbo "mantener", parece funcionar, en la concreta estructura oracional del inc. $3^{\circ}$ art. $315 \mathrm{CP}$, más bien como un "verbo de soporte" y por lo mismo perder gran parte de su potencial semántico en beneficio de del otro verbo contenido en el enunciado: "vender".

${ }^{71}$ En esta medida, el acto de detener el proceso de venta se encuentra prescrito por el ordenamiento jurídico a través de la norma de sanción en comento. En otras palabras, a nivel intencional, el contenido prescriptivo (ilocucionario) de esta norma se condice con un mandato, en el sentido de exigir del destinatario la realización de una acción (que se encuentra típicamente indicada) como prestación positiva de salvaguarda del bien jurídico salud pública En este sentido SILVA SÁNCHEZ, Jesús María, El Delito de Omisión, $2^{\mathrm{a}}$ Ed., Buenos Aires: Editorial B de F, 2006, pp. 352-353.

${ }^{72}$ Y como acción indicada (cuya ausencia determina la producción de una realización típica omisiva) "hay que entender una conducta que, desde una perspectiva ex ante, se estima objetivamente apropiada -más aún necesaria - para la evitación del resultado lesivo del bien jurídico mediante una prestación positiva" SILVA SÁNCHEZ, El Delito de Omisión, cit. nota n $^{\circ} 71$, p. 361.

73 Tal y como señala von Wright, "la actividad humana tiene un principio y un fin. El principio y el fin de una actividad tienen, algunas veces, al menos, el carácter de actos. Correr es una actividad; pero empezar a correr o parar de correr son en cierto modo actos". VON WRIGHT, Norma y Acción, cit. nota n 1, p. 59 . Siguiendo a este autor, creemos que, desde la perspectiva del contenido deóntico del tipo penal del inciso $3^{\circ}$ del Art. 315
} 
SALAZAR, Andrés. "El delito de mantención de la venta de alimentos defectuosos al público: Una revisión del artículo 315 del Código Penal a partir de la teoría de las presunciones y de la dogmática de los delitos de omisión propia”.

En todo caso, el alcance del deber y la determinación de la(s) concreta(s) acción(es) indicada(s) es una cuestión contingente que dependerá en buena medida de la concreta situación de riesgo provocada por la distribución del alimento defectuoso y de la concreta posición que posee el destinatario de la norma en la cadena productiva, en términos de su capacidad para evitar el resultado (y en dicha medida, en relación con la exigibilidad de la conducta hacia el demandada por el ordenamiento jurídico) ${ }^{75}$.

Desde el punto de vista subjetivo, la equiparación de las conductas de "mantener a la venta" con las de "vender" y "distribuir", en el especifico contexto del art. $315 \mathrm{CP}$, exige entender que esa mantención a la venta de los productos alimenticios se debe realizar con el conocimiento de que éstos poseen un carácter nocivo, siendo idóneos para lesionar la salud de eventuales consumidores. En buenas cuentas se trata de un delito que requiere dolo de peligro, de la misma forma que lo exigen los incisos primero y segundo de la misma disposición $^{76}$.

Por otra parte, además del conocimiento de la nocividad de los alimentos, en este nivel de tipicidad, se requiere que, de los antecedentes de hecho que rodean a la tenencia, se pueda desprender que el sujeto responsable de los mismos tenga el ánimo de transferirlos a cambio de dinero.

Finalmente, el delito de la referencia se trata de uno de mera actividad o, en otros términos, de un delito de omisión pura. En efecto, tal como lo ha puesto de relieve la doctrina, los delitos de omisión pura son aquellos respecto a los cuales "no cabe imputar [un] resultado lesivo trascendente a la omisión, cuya no evitación ha venido dada por la no-realización de

$\mathrm{CP}$, su forma lógica sería $\operatorname{Od}(p T \neg p)$, esto es, la de destruir el estado de cosas representado por la variable "p", que en nuestro caso representaría a la situación de mantener a la venta.

${ }^{74}$ En dicha medida, y en un sentido relevante, como acción indicada para detener el proceso de venta del producto nocivo, perfectamente, puede caber la acción de retirar el producto del mercado, en la medida en que dicha actuación sea estimada ex ante como objetivamente idónea - o incluso necesaria- para desactivar la situación de riesgo tomada en consideración por el legislador a la hora de instaurar el presente delito.

${ }^{75}$ Así por ejemplo, si el productor (P) de un determinado alimento (A) ha detectado que un lote de partidas de éste ha resultado contaminado con un agente químico que se revela como riesgoso para la salud de las personas (por su toxicidad, por ejemplo), retira de la venta al público los productos que ofrece en sus propios locales comerciales o a través de su página web y, al mismo tiempo, da aviso a los intermediarios, minoristas o cadenas de retail $(\mathrm{R})$ que también ofrecen el alimento que él produce, poniéndolos en conocimiento de los riesgos que implica la comercialización del mismo e identifica los lotes peligrosos para que ellos sean retirados del mercado, dicho productor $(\mathrm{P})$ no responderá penalmente por la oferta al público de aquellos bienes que continúa realizando el minorista $(\mathrm{R})$, debiendo entenderse que aquél ya cumplió con la acción indicada por la regla penal, mientras que el segundo, podría ser castigado por el delito contemplado en el inciso $3^{\circ}$ del Art. 315 del CP.

${ }^{76}$ Junto con la profesora Mirentxu Corcoy entendemos que el dolo de peligro requiere el conocimiento de la idoneidad del comportamiento que se realiza para lesionar el bien-jurídico penal, debiendo abarcar ese dolo todos los elementos típicos. Así en el caso del delito en estudio, "el dolo supone conocer que el producto es nocivo, en el sentido en que puede afectar de algún modo la salud de las personas y que lo está colocando en el mercado". CORCOY, Delitos de Peligro, cit. nota ${ }^{\circ} 28$, pp. 287-291. En dicha medida, y sobre todo tratándose aquí de un delito de peligro abstracto, no se requiere que el agente sepa con plena exactitud todas las características o propiedades que hacen riesgoso al alimento y qué concretos efectos es probable que produzca en los consumidores. Simplemente basta, como se ha dicho, con que sepa la idoneidad del producto para causar la afectación del bien jurídico-penal de que se trata. 
Polít. crim. Vol. 10, № 19 (Julio 2015), Art. 11, pp. 318-361.

[http://www.politicacriminal.cl/Vol_10/n_19/Vol10N19A11.pdf]

la acción indicada; esto es, se agotan en la aludida no realización",77. Partiendo de esta base, se sigue que, en el caso del delito del inc. $3^{\circ}$ del art. $315 \mathrm{CP}$, la consumación se produciría por el sólo hecho de que el agente no ponga término a la oferta del producto, manteniendo invariable un mundo donde los objetos prohibidos de que se trata permanecen a la venta. De ahí que adquiera gran importancia el tipo subjetivo para efectos de la determinación del momento consumativo, debido a que, si la venta de estas especies no se encuentra acompañada del conocimiento del defecto que ellas padecen, dicha conducta no podrá ser sancionada como delito ${ }^{78}$.

Lo sostenido en estas páginas posee, sin duda alguna, importantes alcances, tanto teóricos como empíricos, de manera tal que si se aceptan las conclusiones aquí alcanzadas, debería cambiar la forma en que comprendemos el sentido y alcance del inc. $3^{\circ}$ del art. 315 del $\mathrm{CP}^{79} \mathrm{y}$, consecuencialmente, la forma en que los tribunales de justicia podrían aplicar los delitos contra la salud pública regulados en esta misma disposición. Dicho de manera muy gráfica a través de un ejemplo, si se acepta esta postura como correcta, probablemente, la definición judicial del caso ADN (al menos en lo que se refiere a la posibilidad de cometer el delito del artículo 315 del CP, por la vía omisiva) podría haber sido muy distinta.

\footnotetext{
${ }^{77}$ SILVA SÁNCHEZ, El Delito de Omisión, cit. nota no 71, p.431.

${ }^{78}$ Esta circunstancia es bien notada por Cox, quien expresa que "[e]n principio (...) respecto de aquellos delitos cuyos tipos no contemplan requisitos distintos a la pura posesión, una vez constatada ésta se clausura la posibilidad de desistir y, con ello - dándose los demás elementos de la definición de delito -, la punición a título de consumación queda garantizada" agregando luego que "en este ámbito tal vez la excepción más notable venga dada por el tipo de posesión de drogas contenido en el art. 368 CP: exige que la posesión sea con alguno de los fines ahí mencionados, de manera tal que la pura posesión, no encaminada a ellos, no supondría todavía consumación: la persecución de esos fines debe entenderse como un elemento subjetivo del tipo que, por tanto, integra el injusto". COX, Delitos de posesión, cit. nota no 62, pp. 236-237. Así, en el caso del delito contenido en el artículo 315 del CP, la tenencia de los alimentos debe estar acompañada tanto del conocimiento de la nocividad de dichos productos, como de la intención de venderlos.

${ }^{79}$ A estos efectos, cabría agregar que, a nuestro juicio, el delito de que se trata, desde una perspectiva material o político criminal, podría ser mejor caracterizado como uno de "omisión pura de garante". Los delitos de omisión pura de garante poseen un fundamento mixto que contempla tanto consideraciones de solidaridad general como otras basadas en circunstancias institucionales (en otras palabras, en ellos se funden las consideraciones materiales que se encuentran tras las usuales categorías dogmáticas conocidas como delitos de omisión propia o pura y aquellas que sustentan a los delitos de omisión impropia o comisión por omisión). Así, "las omisiones puras de garante tienen su fundamento en la existencia de una base funcional específica. Ello determina que sólo puedan ser realizadas por un determinado círculo de sujetos caracterizados por la ostentación de una posición de responsabilidad especial". Sobre los delitos de omisión pura de garante, ver: SILVA, El Delito de Omisión, cit. nota 71, p. 431 y ss. En el caso del delito en análisis, la posición especial de que se trata sería ocupada por todos aquellos que intervienen en la industria alimenticia, industria que posee una innegable importancia para el bienestar (salud) y desarrollo de las personas. Y es que, como bien señala Kuhlen "la comercialización de productos constituye pues, pese a su indiscutible utilidad social una fuente de peligros. Comporta riesgos para la vida e integridad física de los consumidores, por consiguiente para bienes jurídicos protegidos tradicionalmente por el Derecho penal como intereses fundamentales", peligrosidad que aumenta si se considera que en la fabricación y distribución de productos se da "una creciente distancia personal y social, así como un desnivel técnico-científico entre fabricante y usuario (...) circunstancias (...) que limitan considerablemente las posibilidades de control por parte del consumidor". KUHLEN, Lothar, "Cuestiones fundamentales de la responsabilidad penal por el producto", en: MIR PUIG, Santiago; LUZÓN PEÑA, Diego-Manuel. Responsabilidad Penal de las Empresas y sus Órganos y Responsabilidad por el Producto, Barcelona: Bosch Editor, 1996, p. 232.
} 
SALAZAR, Andrés. "El delito de mantención de la venta de alimentos defectuosos al público: Una revisión del artículo 315 del Código Penal a partir de la teoría de las presunciones y de la dogmática de los delitos de omisión propia”.

\section{Excurso: Acerca de la coherencia existente entre el delito de que se trata (y del mandato que en él se contiene) con el ordenamiento jurídico nacional.}

Al haberse argumentado aquí en favor de la existencia, en nuestro sistema legal, de una norma punitiva que se encontraría plasmada en un enunciado jurídico compuesto por un término al que no le ha sido reconocido, con la suficiente claridad, su carácter performativo y en tal medida, la capacidad de constituir tipo penales, puede que el lector mantenga algunas dudas respecto de la posibilidad y legitimidad de incriminar conductas a través de normas de presunción.

Por otra parte, a partir de la calidad de delito de omisión propia que se le ha asignado a tal disposición (y que en la práctica importa que dicha regla establecería ciertos deberes positivos para ciertos ciudadanos), desde una perspectiva política, podría entenderse que un delito como éste implica una mayor injerencia por parte del Estado en esferas de libertad reconocidas a las personas, por lo que se podría cuestionar la legitimidad de un precepto como éste, en la medida en que se entienda que su establecimiento demanda un plus de justificación respecto de aquellas prescripciones constituidas por meras prohibiciones (que, como consecuencia, sólo demandan abstenciones de sus destinatarios, más no prestaciones positivas). Tal circunstancia se vería agravada si al analizar las normas que regulan al sector alimentario (primeros destinatarios de las normas de conductas contenidas en el artículo 315 del CP), no existieran deberes para los productores de alimentos de vigilar su producción y reaccionar ante eventuales crisis sanitarias ${ }^{80}$.

A continuación, intentaré una respuesta a esas posibles objeciones.

\subsection{Acerca de posibles dudas respecto de la constitucionalidad del precepto.}

La proposición normativa que se ha defendido en este estudio afirma que el inciso $3^{\circ}$ del artículo 315 del CP constituye un tipo penal y, como ya sabemos, este tipo penal utiliza en su texto la expresión "presunción". Por su parte, el inciso séptimo del artículo $19 \mathrm{~N}^{\mathrm{o}} 3$ de nuestra Constitución Política declara que "la ley no podrá presumir de derecho la responsabilidad penal”. A partir de esta regulación, entonces, ¿puede plantearse seriamente la posibilidad de que la regla del inciso tercero del artículo 315, por el sólo hecho de incluir la expresión "presunción" resulta inconstitucional a luz de lo prescrito por el referido inciso séptimo del artículo 19 de nuestra carta fundamental?

Para resolver esta cuestión debemos, primero, estudiar el contenido de la prohibición establecida en la Constitución para luego contrastarla con la regla del Código Penal.

En primer lugar, cabe hacer presente que es claro que la regla constitucional se refiere a aquellas presunciones de carácter probatorio (esto es, aquellas que establecen legalmente relaciones de inferencia entre un hecho desconocido y uno no conocido) que, además,

\footnotetext{
${ }^{80}$ Así, por ejemplo, Contreras, al analizar (solamente) el inciso segundo del art. 315 del CP ha puesto en

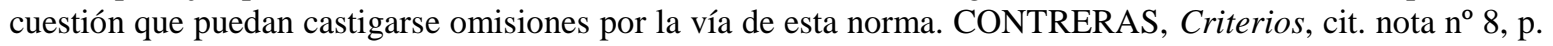
16.
} 
Polít. crim. Vol. 10, № 19 (Julio 2015), Art. 11, pp. 318-361.

[http://www.politicacriminal.cl/Vol_10/n_19/Vol10N19A11.pdf]

poseen la característica de no poder ser refutadas por prueba en contrario aportada por la parte que se ve afectada por ella.

En este orden ideas, tal y como ha sostenido Rodríguez Collao, el sentido de la prohibición constitucional "es el de impedir que la ley presuma los presupuestos fácticos de la responsabilidad penal, los cuales, atendida su naturaleza, si pueden ser objeto de presunción"81. En otras palabras, la disposición constitucional de que se trata, efectivamente tiene un sentido procesal inequívoco, encontrándose referida a la prohibición de asumir de derecho, y sin posibilidad de refutación alguna, que el imputado ha realizado el acto penado por la ley ${ }^{82}$.

En dicha medida, debe aceptarse que la mencionada prohibición constitucional no alcanza al inciso tercero del artículo 315 del CP, ya que, como se ha demostrado, esta norma no constituye una regla probatoria, sino un tipo penal. Por lo mismo, tampoco puede hablarse de alguna afectación al principio de inocencia ya que, como ocurre con la acreditación cualquier delito, en este caso, la carga de la prueba de los hechos típicos sigue pesando sobre los hombros del Ministerio Público, organismo que deberá demostrar que el imputado ha mantenido a la venta el alimento infectado, envenenado, adulterado o deteriorado en un lugar de libre acceso al público, a pesar de conocer su nocividad.

Tampoco podría reprochársele a esta norma una contradicción con el principio de tipicidad incluido en el inciso final del artículo $19 \mathrm{~N}^{\mathrm{o}} 3$ de la Constitución. Y es que, en efecto, la conducta penada se encuentra claramente determinada en la disposición en análisis: tener a la venta en lugares de libre acceso al público alimentos que se hayan transformado en nocivos por su infección, envenenamiento, adulteración o por el menoscabo apreciable de sus propiedades alimenticias.

De esta forma, la formulación empleada por el legislador, en lo que se refiere a la descripción de la conducta incriminada se describe de manera clara y precisa, cumpliendo con el referido mandato constitucional.

\footnotetext{
${ }^{81}$ RODRÍGUEZ, "Sobre la constitucionalidad", cit. nota n ${ }^{\circ} 55$, p. 341.

${ }^{82} \mathrm{Al}$ respecto, debe tenerse presente que, de acuerdo a las Actas de la Constitución Política de la República de 1980, el comisionado Miguel Schweitzer definió el alcance de la prohibición contenida en el actual inciso séptimo del art. 19 № 3, señalando que "lo enteramente inadmisible es que por la vía de las presunciones de derecho se dé por establecida, ya sea la existencia del hecho como constitutivo de delito o el grado de participación que el sujeto tenga en él...". Acta de sesión de la Comisión Redactora No 124, de martes 27 de mayo de 1975, citada por RODRÍGUEZ, "Sobre la constitucionalidad", cit. nota n 55, p. 341. En un sentido similar, el profesor José Luís Cea ha expresado que "la razón de ser [de este] precepto constitucional es [la de] reconocer al afectado todas las posibilidades de demostrar su inocencia, por lo cual estamos ante un requisito esencial del debido proceso". CEA, José Luís, Derecho Constitucional Chileno, T. II., Santiago: Ediciones Universidad Católica de Chile, 2003, p. 166.
} 
SALAZAR, Andrés. "El delito de mantención de la venta de alimentos defectuosos al público: Una revisión del artículo 315 del Código Penal a partir de la teoría de las presunciones y de la dogmática de los delitos de omisión propia”.

\subsection{Respecto de la coherencia de la norma en estudio con el orden jurídico primario (Derecho Alimentario).}

Sobre este punto, solo resta señalar que norma contemplada en el inciso tercero del artículo $315 \mathrm{CP}$ viene a reforzar punitivamente una serie de disposiciones que se encuentran ya incorporadas en el Derecho Alimentario chileno.

En efecto, el tipo penal en comento no es sino una reafirmación de las normas de conductas incluidas en el derecho sectorial, y que guían el correcto desempeño de la industria alimenticia.

Esto es evidente cuando se compara lo dispuesto en el artículo 315 incisos primero, segundo y tercero del Código Penal con lo prescrito por los artículos 104 inciso $2^{\circ}$ del Código Sanitario ${ }^{83}$ y los artículos $1^{\circ}$ y 102 del Reglamento Sanitario de Alimentos ${ }^{84}$.

Todas estas normas prohíben la fabricación y expendio de alimentos defectuosos, y se basan en el principio de inocuidad alimentaria que inspira a toda la regulación sectorial ${ }^{85}$.

\section{Conclusiones.}

A través del transcurso de estas páginas hemos comprobado que existe un delito en el ordenamiento jurídico chileno que sanciona a quien mantiene a la venta alimentos envenenados, infectados, adulterados o con menoscabo apreciable de sus propiedades nutricionales cuando ellos sean capaces de poner en riesgo la salud de los consumidores.

Tal delito forma parte de nuestras normas de responsabilidad penal por el producto y constituye un delito de omisión propia que obliga al destinatario de la misma a realizar las acciones posibles y necesarias de ejecutar para desactivar el riesgo que ha creado con la puesta en circulación de un bien peligroso.

\footnotetext{
${ }^{83}$ Artículo 104.- Los productos alimenticios deberán responder a sus caracteres organolépticos y, en su composición química y características microbiológicas, a sus nomenclaturas y denominaciones legales y reglamentarias.

Se prohíbe la fabricación, importación, tenencia, distribución y transferencia, a cualquier título, de productos alimenticios contaminados, adulterados, falsificados o alterados.

${ }^{84}$ ARTÍCULO 102.- Se prohíbe la fabricación, importación, tenencia, distribución, comercialización o transferencia a cualquier título, de alimentos alterados, contaminados, adulterados o falsificados.

${ }^{85}$ A esto se suma el hecho de que la Norma Chilena 2861-2011 (norma que si bien no ha sido oficializada aún por Decreto Supremo, contiene los estándares técnicos que el sector alimenticio considera elementales para la manufactura y venta de dichos productos), entre otras obligaciones dirigidas a quienes participan del mercado alimentario nacional, contiene los deberes de dar aviso a la autoridad sanitaria y de retirar del mercado el producto alimenticio (a través del procedimiento denominado "Recall") en casos de emergencia. Cabe hacer presente que el seguimiento de la Norma Chilena 2861 (en su versión anterior, donde el recall figuraba a nivel de recomendación y no a nivel perentorio, como es en su versión 2011) es obligatorio para los productores de alimentos de acuerdo a lo prescrito por el Artículo 69 del Reglamento Sanitario de Alimentos. Además, el mismo reglamento impone claros deberes de vigilancia a parte relevante de los actores del sector, ya que por disposición del mismo artículo 69, ciertos productores se encuentran obligados a "implementar las metodologías de análisis de peligros y puntos críticos, en toda su línea de producción”, además de lo cual se encuentran obligados a cumplir con las "Buenas Prácticas de Fabricación” que se incluyen en dicha norma.
} 
Polít. crim. Vol. 10, № 19 (Julio 2015), Art. 11, pp. 318-361.

[http://www.politicacriminal.cl/Vol_10/n_19/Vol10N19A11.pdf]

En el camino emprendido hacia la confirmación de nuestra tesis (proposición normativa) hemos debido enfrentar un problema: la determinación del real alcance del término presunción en el contexto jurídico. Acudiendo a la concepción plural de las presunciones sostenida por la moderna Teoría del Derecho hemos podido apreciar que en el lenguaje jurídico la referida expresión se utiliza fundamentalmente con dos finalidades: (1) establecer reglas de razonamiento probatorio o (2) configurar hechos institucionales. Es a esta segunda forma de emplear el término a la que acudió el legislador para configurar el delito en comento.

El adecuado reconocimiento del inciso tercero del artículo 315 del CP como norma de sanción trae consigo una serie de efectos pragmáticos de singular relevancia, debiendo ser tenida en cuenta ésta como una norma de una importante potencialidad prescriptiva, tanto para la guía de la conducta de los agentes que participan del mercado alimentario como para la de los órganos encargados de aplicar la sanción penal ante la infracción de la referida disposición.

Del simple hecho de que la existencia de la norma aquí identificada no haya sido advertida por la mayor parte de nuestra doctrina y jurisprudencia no se sigue en absoluto su ilegitimidad como tipo penal. Y es que, la tradición no constituye argumento.

Muy por el contrario, interpretada de conformidad a su real alcance, como se ha podido apreciar, la norma en comento cumple con todos los estándares político-jurídicos consagrados a nivel constitucional para reconocerle legitimidad a las normas penales.

Finalmente, desde un análisis contextual, es posible apreciar que la disposición de que se trata es coherente con las normas primarias de obligación contenidas en el derecho sanitario y regulatorio que rige a la industria alimentaria, reforzando sus disposiciones por la vía de la sanción penal, para las infracciones más graves, aquellas que ponen en peligro importantes bienes jurídico-penales tanto colectivos como individuales. 
SALAZAR, Andrés. "El delito de mantención de la venta de alimentos defectuosos al público: Una revisión del artículo 315 del Código Penal a partir de la teoría de las presunciones y de la dogmática de los delitos de omisión propia”.

\section{BIBLIOGRAFÍA.}

AGUILÓ-REGLA, Josep, "Nota sobre “presunciones” de Daniel Mendoca”, Doxa no 22 (1999).

ALEXY, Robert, Teoría de los Derechos Fundamentales, $2^{\mathrm{a}}$ Ed., Madrid: Centro de Estudios Políticos y Constitucionales, 2008.

AUSTIN, John L., Cómo Hacer Cosas con Palabras, Barcelona: Editorial Paidos, $2^{\mathrm{a}}$ Ed., 2003.

, "Emisiones realizativas", en: VALDÉS VILLANUEVA, Luís (Compilador), La Búsqueda del Significado, Madrid: Editorial Tecnos, 2005

BULYGUIN, Eugenio, "La importancia de la distinción entre normas y proposiciones normativas", en: BULYGUIN, Eugenio; ATIENZA, Manuel; BAYÓN, Juan Carlos, Problemas lógicos en la teoría y práctica del Derecho. Madrid: Fundación Coloquio Jurídico Europeo, 2009.

CONTRERAS, Lautaro, Criterios para la determinación de los deberes del productor, Santiago: Colegio de Abogados de Chile, 2012.

, Normative Kriterien zur Bestimmung der Sorgfaltspflichten des Produzenten, Berlin: Editorial Duncker\&Humblot, 2012.

CORCOY, Mirentxu, Delitos de Peligro y Protección de Bienes Jurídicos Supraindividuales. Nuevas formas de delincuencia y reinterpetación de tipos penales clásicos, Valencia: Editorial Tirant Lo Blanch, 1999.

, "Responsabilidad penal derivada del producto. En particular la regulación legal en el Código Penal Español: Delitos de Peligro". En: MIR PUIG, Santiago; LUZÓN PEÑA, Diego-Manuel. Responsabilidad Penal de las Empresas y sus Órganos y Responsabilidad por el Producto, Barcelona: Bosch Editor, 1996.

COX, Juan Pablo, Delitos de Posesión. Bases para una dogmática, Buenos Aires: Editorial B de F, 2012.

CURY, Enrique, Derecho Penal, Parte General, $8^{\mathrm{a}}$ Ed., Santiago: Ediciones Universidad Católica, 2005.

DANNECKER, Gerhard, "Derecho Penal Alimentario Europeo", en: TIEDEMANN, Klaus, (Dir.), Eurodelitos. El Derecho Penal Económico en la Unión Europea, Cuenca: Ediciones Universidad de Castilla de la Mancha, 2003

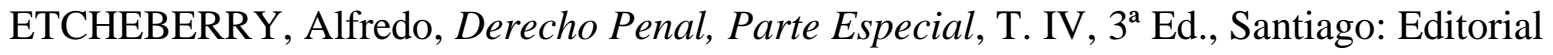
Jurídica de Chile, 1998.

FRAMARINO DEI MALATESTA, Nicola, Lógica de las Pruebas en Materia Criminal, Vol. I., 4ª Ed., Bogotá: Editorial Themis, 1988.

GAMA, Raymundo, "Concepciones y tipología de las presunciones en el Derecho continental”, Revista de Estudios de la Justicia № 19 (2013).

GARRIDO, Mario, Derecho Penal, T. IV, $3^{\mathrm{a}}$ Ed., Santiago: Editorial Jurídica de Chile, 2005.

HEFENDEL, Roland, “¿Debe ocuparse el Derecho Penal de Riesgos Futuros? Bienes jurídicos colectivos y delitos de peligro abstracto", Revista Electrónica de Ciencia Penal y Criminología no 4 (2002), en: http://criminet.ugr.es/recpc/recpc 04-14.pdf. 
Polít. crim. Vol. 10, No 19 (Julio 2015), Art. 11, pp. 318-361.

[http://www.politicacriminal.cl/Vol_10/n_19/Vol10N19A11.pdf]

HERNÁNDEZ, Héctor, "El problema de la "causalidad general" en el derecho penal chileno (con ocasión del art. 232 del Anteproyecto de Nuevo Código Penal)", Polít. crim. $\mathrm{n}^{\mathrm{o}} 1$ (2006).

HERNÁNDEZ MARÍN, Rafael, Introducción a la Teoría de la Norma Jurídica, 2ª Ed., Madrid: Marcial Pons.

KINDHÄUSER, Urs, "Estructura y legitimación de los delitos de peligro del Derecho Penal", Trad. PASTOR MÚÑ̃Z, Nuria, en: KINDHÄUSER, Urs, Teoría de las normas y sistemática del delito, Lima: Ara Editores, 2008.

KUHLEN, Lothar, "Cuestiones fundamentales de la responsabilidad penal por el producto", en: MIR PUIG, Santiago; LUZÓN PEÑA, Diego-Manuel. Responsabilidad Penal de las Empresas y sus Órganos y Responsabilidad por el Producto, Barcelona: Bosch Editor.

LABATUT, Gustavo, Derecho Penal, T. II., Santiago: Editorial Jurídica, 2000.

MALDONADO, Francisco, "Reflexiones sobre las técnicas de tipificación de los llamados "delitos de peligro" en el moderno Derecho Penal", Revista de Estudios de la Justicia, $\mathrm{n}^{\circ} 7$ (2006)

MAÑALCH, Juan Pablo, Norma, Causalidad y Acción, Madrid: Editorial Marcial Pons, 2014.

MENDOCA, Daniel, Las claves del derecho, Barcelona: Editorial Gedisa, 2008. "Presunciones", DOXA No 21 (1998).

OSSANDÓN, María Magdalena, La Formulación de Tipos Penales. Santiago: Editorial Jurídica de Chile, 2009.

PASTOR, NURIA. Los delitos de posesión y los delitos de estatus: una aproximación político criminal y dogmática, Barcelona: Editorial Atelier, 2005.

PUGA, Juan, Derecho Concursal. Delitos de la quiebra, $2^{\mathrm{a}}$ Ed., Santiago: Editorial Jurídica de Chile, 2002.

REIG, Assela, "Una clasificación de los verbos realizativos en Español". En: FACE, Timothy y KLEE, Carol, Selected proceeedings of the $8^{\text {th }}$ Hispanic Linguistics Symposim. USA: Cascadilla Proceeding Project, 2006.

RODRÍGUEZ, Luís, "Sobre la constitucionalidad del tipo de fraude aduanero", Revista de Derecho de la Universidad Católica de Valparaíso, nº 15 (1993).

RODRÍGUEZ, Luís; OSSANDÓN, María Magdalena, Delitos Aduaneros, Santiago: Editorial Jurídica de Chile, 2011.

SCHAUER, Frederic, Las Reglas en Juego, Madrid: Editorial Marcial Pons, 2004.

SCHROEDER, Friedrich-Christian, "La posesión como hecho punible", Revista de Derecho Penal y Criminología, $2^{\text {a }}$ época, no 14 (2004).

SILVA SÁNCHEZ, Jesús María, El Delito de Omisión, 2a Ed., Buenos Aires: Editorial B de F, 2006.

SEARLE, John, Actos de Habla, Madrid: Editorial Cátedra, 6 ${ }^{\text {a }}$ Ed., 2007. , La Construcción de la Realidad Social, Barcelona: Editorial Paidos, 1997. , Mente, Lenguaje y Sociedad, Madrid: Editorial Alianza, 2004.

SILVA CANCINO, Mauricio, Las presunciones judiciales y legales, $2^{\mathrm{a}}$ E., Santiago: Editorial Jurídica Cono Sur, 1995.

STRUENSSE, Eberhard, "Los delitos de tenencia”, en: JAKOBS, Günter y STRUENSSE, Eberhard. Problemas capitales del derecho penal moderno, Buenos Aires: Editorial Hamurabi, 1998. 
SALAZAR, Andrés. "El delito de mantención de la venta de alimentos defectuosos al público: Una revisión del artículo 315 del Código Penal a partir de la teoría de las presunciones y de la dogmática de los delitos de omisión propia”.

TIEDEMANN, Klaus, Manual de Derecho Penal Económico: Valencia: Editorial Tirant Lo Blanch, 2010.

VALENZUELA, Jonatan, "Presumir la responsabilidad: Sobre una relación entre la prisión preventiva y la presunción de inocencia en el Derecho Procesal Penal chileno", Revista de Estudios de la Justicia, № 14 (2011), pp. 53-69.;

"Inocencia y Razonamiento Probatorio", Revista de Estudios de la Justicia, No 18, (2013), pp. 13-22

VAN WEEZEL, Alex, "Autoría y responsabilidad por el producto: ¿participación en decisiones de órganos colegiados como intervención delictiva?”, en: DEL MISMO, Pena y Sentido. Estudios de Derecho Penal, Lima: Editorial Ara, 2008.

VARGAS, Tatiana, Delitos de Peligro Abstracto y Resultado. Determinación de la incertidumbre penalmente relevante, Pamplona: Editorial Aranzadi, 2007.

VON WRITH, George, Norma y acción. Una investigación Lógica, Madrid: Editorial Tecnos.

Normas, verdad y lógica. México: Editorial Fontamara, 2010.

WITTGENSTEIN, Ludwig, Sobre la certeza, Barcelona: Editorial Gedisa, 2006. , Tractatus Logico-philosophicus, Madrid: Alianza Editorial, 2003. , Investigaciones Filosóficas, Barcelona: Editorial Crítica, 2008.

ZARATE, Manuel, "Delitos contra la salud pública. Algunos comentarios a partir de una sentencia condenatoria por el delito previsto en el artículo 314 del Código Penal", Revista Jurídica del Ministerio Público, No 37 (2008). 